\title{
Physical and chemical properties of pollution aerosol particles transported from North America to Greenland as measured during the POLARCAT summer campaign
}

\author{
B. Quennehen ${ }^{1}$, A. Schwarzenboeck ${ }^{1}$, J. Schmale ${ }^{2}$, J. Schneider ${ }^{2}$, H. Sodemann ${ }^{3, *}$, A. Stohl ${ }^{3}$, G. Ancellet ${ }^{4}$, \\ S. Crumeyrolle ${ }^{1, * *}$, and K. S. Law ${ }^{4}$ \\ ${ }^{1}$ Laboratoire de Météorologie Physique, Université Blaise Pascal, CNRS UMR6016, Aubière, France \\ ${ }^{2}$ Particle Chemistry Department, Max Planck Institute for Chemistry, Mainz, Germany \\ ${ }^{3}$ Norwegian Institute for Air Reasearch (NILU), Kjeller, Norway \\ ${ }^{4}$ UPMC Univ. Paris 06, Université Versailles St-Quentin, CNRS/INSU, LATMOS-IPSL, UMR8190, Paris, France \\ *now at: Swiss Federal Institute of Technology, Zurich, Switzerland \\ ** now at: NASA Langley Research Center, Hampton, Virginia, USA
}

Received: 28 March 2011 - Published in Atmos. Chem. Phys. Discuss.: 15 April 2011

Revised: 20 October 2011 - Accepted: 26 October 2011 - Published: 4 November 2011

\begin{abstract}
Within the framework of the POLARCAT-France campaign, aerosol physical, chemical and optical properties over Greenland were measured onboard the French ATR-42 research aircraft. The origins of $\mathrm{CO}$ excess peaks detected in the aircraft measurements then have been identified through FLEXPART simulations. The study presented here focuses particularly on the characterization of air masses transported from the North American continent to Greenland. Air masses that picked up emissions from Canadian boreal forest fires as well as from the cities on the American east coast were identified and selected for a detailed study. Measurements of $\mathrm{CO}$ concentrations, aerosol chemical composition, aerosol number size distributions, aerosol volume volatile fractions and aerosol light absorption (mainly from black carbon) are used in order to study the relationship between $\mathrm{CO}$ enhancement $(\triangle \mathrm{CO})$, aerosol particle concentrations and number size distributions. Aerosol number size distributions (normalised with their respective $\Delta \mathrm{CO}$ ) are in good agreement with previous studies. Nonetheless, wet scavenging may have occurred along the pathway between the emission sources and Greenland leading to a less pronounced accumulation mode in the POLARCAT data. Chemical analyses from mass spectrometry show that submicrometer aerosol particles are mainly composed of sulphate and organics. The observed bimodal (Aitken and accumulation) aerosol number size distributions show a significant enhancement in Aitken mode particles. Furthermore, results from the thermodenuder anal-
\end{abstract}

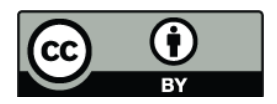

Correspondence to: B. Quennehen (b.quennehen@opgc.univ-bpclermont.fr) ysis demonstrate the external mixture of boreal fire (BF) air masses from North America (NA). This is particularly observed in the accumulation mode, containing a volume fraction of up to $25-30 \%$ of refractory material at the applied temperature of $280^{\circ} \mathrm{C}$. NA anthropogenic air masses with only $6 \%$ refractory material in the accumulation mode can be clearly distinguished from BF air masses. Overall, during the campaign rather small amounts of black carbon from the North American continent were transported towards Greenland during the summer POLARCAT observation period, which also is a valuable finding with respect to potential climate impacts of black carbon in the Arctic.

\section{Introduction}

The Polar regions are known to be more strongly impacted by global warming than other regions (IPCC, 2007). Many studies have been carried out to improve our current understanding on climate processes related to short lived climate forcers in the Arctic atmosphere (Law and Stohl, 2007), while most of the previous work was based on surface observations (Sirois and Barrie, 1999; Ricard et al., 2002; Quinn et al., 2002, 2008). Few airborne campaigns have been performed to date (Shaw, 1975; Schnell, 1984; Brock et al., 1990; Browell et al., 1992; Dreiling and Friederich, 1997). Furthermore, many advances in measurement techniques, especially for aerosol measurements (aerosol mass spectrometry, aerosol light absorption, aerosol volume volatility), have been achieved recently (Bond et al., 1999). That is why the POLARCAT (POLar study using Aircraft, Remote sensing,

Published by Copernicus Publications on behalf of the European Geosciences Union. 
surface measurements and models, of Climate, Chemistry, Aerosols and Transport) project was launched during the 4th International Polar Year (IPY) (2007-2008). The principal objective within the French POLARCAT program has been to increase our knowledge about long range transport of short-lived pollutants (particulates and gases) to the Arctic. The French ATR-42 research aircraft performed 24 scientific flights out of Kiruna, Sweden, in spring (not treated in this study) and twelve flights from Kangerlussuaq, Greenland, in summer 2008. For the campaign, the ATR-42 was equipped with instrumentation measuring the physical, opti$\mathrm{cal}$, and chemical properties of the aerosols.

Aerosol particles play a major role in global climate change (IPCC, 2007) through direct and indirect effects (Twomey, 1977) on Earth's radiative budget. Especially in the Arctic region, these effects remain poorly investigated and are therefore difficult to quantify, thus implicating large uncertainties (Garrett and Zhao, 2006; Lubin and Vogelmann, 2006). In principle, the Arctic region is characterised by very few pollution sources. However, transport of pollution from outside the Arctic leads to the build up of Arctic Haze, initially observed by pilots flying over Arctic regions (Greenaway, 1950; Mitchell, 1957), and more recently studied by Dreiling and Friederich (1997). A good summary of actual knowledge about aerosols in the Arctic is given in Quinn et al. (2007). The Arctic Haze is composed by a majority of sulphate and particulate organic matter and, to a lesser extent, black carbon (Quinn et al., 2002). It originates from forest fires (which are included in the denomination "biomass burning", see the overview by Reid et al. (2005)) and/or anthropogenic pollution sources originating from various regions in the northern hemisphere like Europe, Siberia, China, or North America. While Eckhardt et al. (2003) show that the North Atlantic Oscillation controls air pollution transport to the Arctic, it is not clear yet which source is the largest contributor to the Arctic haze. Stohl (2006), Sharma et al. (2004, 2006) and very recently, in the frame of the ARCPAC campaign, Hirdman et al. (2010), Huang et al. (2010) and Brock et al. (2011) agreed that a major influence stems from the Eurasian sector, including Europe, former USSR, Siberia and Northern China, particularly during the winter and spring seasons. While most recently some efforts have been made to characterise the impact of air masses originating from Eurasia (Sharma et al., 2004, 2006; Stohl, 2006; Stohl et al., 2007; Paris et al., 2009, 2010), longrange transport of North American pollution has been studied to a lesser extent through ice core (McConnell et al., 2007) and model analyses (Hirdman et al., 2010). North American pollution plumes have been studied principally in midlatitude regions (Honrath et al., 2004; Fiebig et al., 2003; Petzold et al., 2007). During summer, in general Arctic haze does not occur, because of the reduced extent of the polar vortex and significant aerosol removal by wet deposition (Quinn et al., 2007). In summer, boreal fires burning in highlatitude Asia and North America are likely to be more im- portant contributors to Arctic pollution as compared to midlatitude regions (Stohl et al., 2006; Iziomon et al., 2006; Paris et al., 2009). This study aims at characterising aerosol particles transported from North-American pollution sources to Greenland during the Arctic summer and their consequences for the Arctic climate. After presenting an overview of the ATR-42 instrumentation, analysis of measured chemical and physical aerosol properties (aerosol number size distributions, sulphate and organic mass concentrations, aerosol volume volatility and aerosol absorption) are presented, in order to characterise the composition of Aitken and accumulation modes, related to emission sources and transformation processes during transport.

\section{ATR-42 aircraft measurements}

During summer 2008 the French research aircraft ATR-42, based in Kangerlussuaq, Greenland performed 12 scientific flights with extensive aerosol measurements. Figure 1 presents all 12 flight tracks. In general, flights performed during the first part of the campaign (on 5, 7 and 8 July) targeted North American air masses, whereas flights on 12, 13 and 14 focused on Siberian fires. Flights on 5 and 7 July were performed in rather clean air as compared to the 8 July flight. In addition, North American air masses were also sampled during flights on 12,13 and 14 July. Since the focus of this study is entirely dedicated to air masses transported from North America, Siberian air masses are not considered here. All pollution plumes (and thus flight periods) discussed in this study, with air masses originating from the North American continent are highlighted in Fig. 1. It is important to notice that the POLARCAT-France flights operating over Southern Greenland may not have sampled Arctic air masses as such but rather air masses on their way into and out of the Arctic, as the Arctic front is typically situated around $70^{\circ} \mathrm{N}$ in summer (Quinn et al., 2005).

\subsection{Physical aerosol properties}

Measurements of the aerosol particle size distributions onboard the aircraft were performed using a combination of a Scanning Mobility Particle Sizer (SMPS) described by Villani et al. (2008) and an Optical Particle Counter (OPC, GRIMM model 1.108), both operated inside the aircraft cabin downstream of the ATR-42 Community Aerosol Inlet (CAI). The CAI is similar to the one designed for the University of Hawaii McNaughton et al. (2007). A Passive Cavity Aerosol Spectrometer Probe (PCASP 100-X, Droplet Measurement Technology (DMT)), was operated outside the aircraft fuselage. While the SMPS sizes aerosol particles of diameters in the range $20<D_{\mathrm{p}}<467 \mathrm{~nm}$ over 88 channels, the OPC measures in the range $300<D_{\mathrm{p}}<2000 \mathrm{~nm}$ over 8 channels, and finally the PCASP in the range $100<D_{\mathrm{p}}<$ $3000 \mathrm{~nm}$ over 30 channels. 


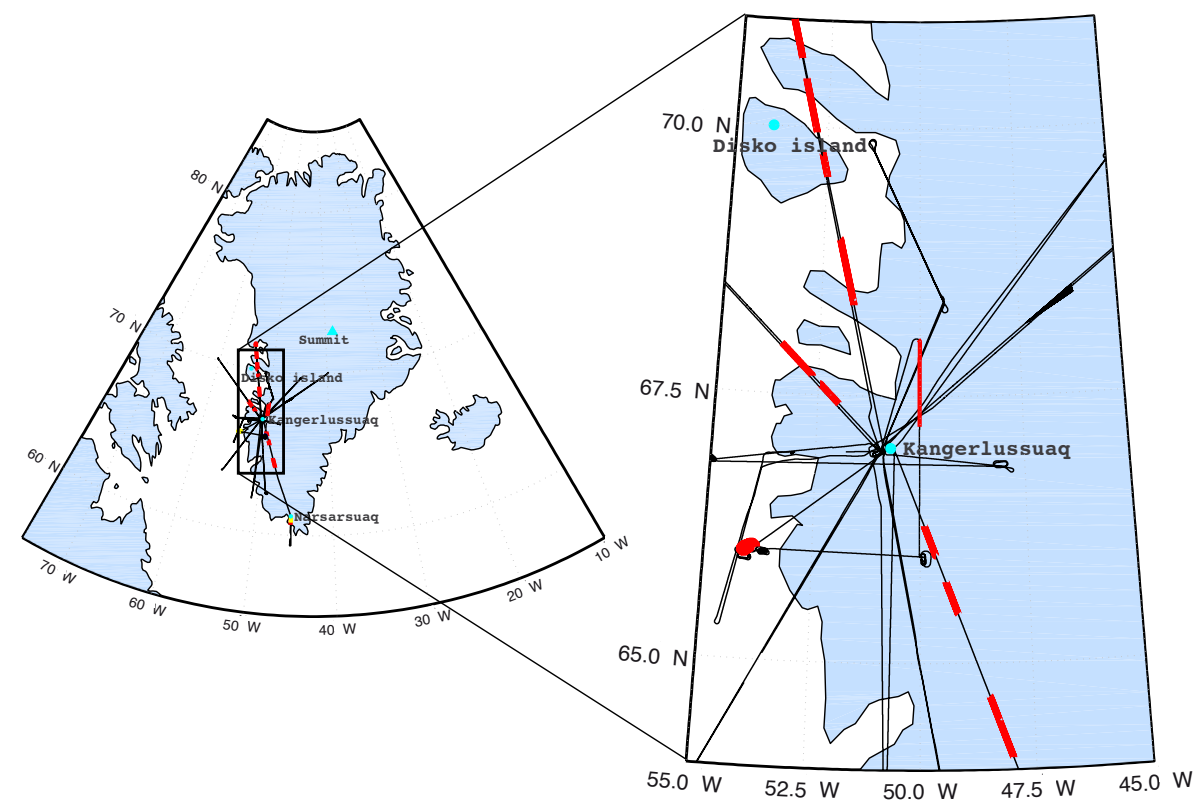

Fig. 1. ATR-42 flight trajectories during the POLARCAT-France summer campaign. Flight segments related to air mass origins from the North American continent studied in this paper are highlighted in red for Canadian forest fires and in yellow for anthropogenic air masses. The anthropogenic air mass was sampled in southern Greenland (Narsassuaq), thus, the sampling period is not represented in the zoom.

The SMPS system consisted of a TSI model 3010 condensation particle counter (CPC), a DMA (Differential Mobility Analyzer) as described by Villani et al. (2007) and a krypton aerosol neutralizer (Kr-85). SMPS electrical mobility distributions (in number) have been converted to number size distributions. The SMPS system and inversion algorithm have been evaluated within the frame of EUSAAR (European Supersites for Atmospheric Aerosol Research). The PCASP is regularly calibrated at DMT with latex spheres (refractive index 1.59). PCASP and SMPS instruments measure dry aerosol particles sizes, since both instruments are working with dry sheath air. For the discussion of the aerosol number size distributions, we used the combination of SMPS and PCASP instruments to cover the largest possible size range measured during the campaign. The PCASP was chosen because of its narrower channels compared to the OPC (30 channels for the PCASP against 8 for the OPC). In principle, because of the aerosol refractive index variability, PCASP data have to be corrected based on the Lorentz-Mie theory (Bohren and Huffman, 1983). With respect to the measurement performed on the ATR-42 during the POLARCAT summer campaign, we do not consider the chemical information (no information about sea salt, mineral particles, chemical composition of supermicron particles...) to be sufficient in order to deduce a non-ambiguous size dependent complex refractive index. This means that correcting the PCASP data for another complex refractive index would not have been rigorous. Thus, we decided to keep the size spectra as given for the calibration refractive index of latex spheres for this study. To merge SMPS and PCASP data we decided to linearly weight the SMPS spectrum from 1 to 0 and the PCASP data from 0 to 1 , respectively, within the common size range.

In order to study aerosol particle volatility, another pair of SMPS and OPC instruments (called hereafter NVSMPS/NVOPC) was operated simultaneously downstream of a thermodenuder set to $280^{\circ} \mathrm{C}$. Refractory particles recovered after the thermal conditioning are mainly composed of soot, sea salt, mineral dust and the refractory fraction of organic carbon. The ratio of the volatilized particulate volume (total volume minus refractory volume) and the total particulate volume, assuming spherical particles, is used to retrieve information about aerosol volume volatility within the integral size range of SMPS/OPC instruments. Thus, NVSMPS/NVOPC measurements may be used to estimate the refractory mass assuming this mass to be composed mainly of black carbon with a density of $1.8 \mathrm{~g} \mathrm{~cm}^{-3}$ (Bond and Bergstrom, 2006; Barnard et al., 2007). Because of possible additional presence of other refractory compounds, with different particle densities (e.g. $2.6 \mathrm{~g} \mathrm{~cm}^{-3}$ for dust particles), calculated refractory or volatile mass fractions are related to the instrumental method used in this study. Thus, the conversion into $\mathrm{BC}$ mass fractions must be considered with some caution. In general, a density of $1.7 \mathrm{~g} \mathrm{~cm}^{-3}$ has been used to determine aerosol particle mass concentrations from the SMPS/OPC size spectra at ambient temperature. 


\subsection{Chemical composition and trace gases}

The chemical composition of submicron aerosol particles was determined by a Compact Time-of-Flight Aerosol Mass Spectrometer (C-ToF-AMS, Aerodyne Research, Schmale et al., 2010). The AMS instrument samples aerosol through an aerodynamic lens system which focuses the particle beam onto a vaporizer operated at $600^{\circ} \mathrm{C}$. Before reaching the vaporizer, the particles pass through a time-of-flight region in a vacuum chamber that allows for particle size determination. The vapour is ionized by $70 \mathrm{eV}$ electrons, and the generated ions are analysed in a time-of-flight mass spectrometer. For a detailed description of the C-ToF-AMS see Canagaratna et al. (2007) and Drewnick et al. (2005). During the POLARCAT-France summer campaign, particulate sulphate and organic matter were determined for STP (standard temperature and pressure) conditions with a time resolution of $30 \mathrm{~s}$. The respective detection limits were 0.06 and $0.36 \mu \mathrm{g} \mathrm{m}^{-3}$ on average during the campaign. The AMS also measure ammonium, nitrate and chloride mass concentrations but these are not shown since they were usually below the detection limit. To compensate for the decreasing mass flow into the instrument with increasing altitude a Pressure Controlled Inlet (PCI) was installed upstream of the standard AMS inlet system, also guaranteeing isokinetic sampling from the aircraft aerosol inlet (for an extended description of the inlet system and the characterisation of the PCI see Schmale et al., 2010). The specific set-up on the ATR-42 allowed for sampling of particles in the size range between 80 and $1000 \mathrm{~nm}$ vacuum aerodynamic diameter.

Carbon monoxide (CO) was measured by the MOZART $\mathrm{CO}$ instrument, based on the gas filtered correlation principle of infrared absorption by the $4.67 \mu \mathrm{m}$ fundamental vibrationrotation band of $\mathrm{CO}$ and presented in detail by Nédélec et al. (2003). CO is considered to be an inert tracer over timescales of 10-20 days for air masses influenced by combustion processes such as biomass burning and anthropogenic pollution plumes (Forster et al., 2001) at the latitudes considered in this study. Ozone measurements are also available but not discussed here.

\subsection{Aerosol optical properties}

Beside the instrumentation for physico-chemical analysis of aerosol particles, the ATR-42 was equipped with instrumentation to measure aerosol optical properties: a Particle Soot Absorption Photometer (PSAP, Bond et al., 1999) operated at a wavelength of $565 \mathrm{~nm}$ and an aerosol nephelometer (TSI 3563, TSI Inc., St Paul, MN) which measures the light scattering coefficient $\left(\sigma_{\mathrm{sca}}\right)$ at three different wavelength $(450$, 550 and $700 \mathrm{~nm}$ ). The PSAP instrument has a detection limit of $10^{-6} \mathrm{~m}^{-1}$ for the aerosol light absorption coefficient $\left(\sigma_{\text {abs }}\right)$ which can be reduced using the method described by Springston and Sedlacek (2007). An estimation of the ab- sorbing aerosol mass (massabs) was deduced using the relationship:

mass $_{\mathrm{abs}}=\frac{\sigma_{\mathrm{abs}}}{\beta_{\mathrm{sp}-\mathrm{abs}}}$

where $\beta_{\mathrm{sp}-\text { abs }}$ is the specific absorption coefficent assumed to be $11.6 \mathrm{~m}^{2} \mathrm{~g}^{-1}$. This value has been found by Sharma et al. (2002) at the Alert (Canada) research station for the PSAP instrument at its wavelength of $565 \mathrm{~nm}$. The mass of absorbing matter related to the initial detection limit is $90 \mathrm{ng} \mathrm{m}^{-3}$. In our case, the PSAP raw transmission signal was smoothed with a 180-s running average, thus decreasing the detection limit to $1.75 \times 10^{-7} \mathrm{~m}^{-1}$, corresponding to a mass of $15 \mathrm{ng} \mathrm{m}^{-3}$. Even with this improved detection limit, PSAP measurements are often found to be below or just slightly above the detection limit.

\subsection{Evaluation of data quality}

In order to investigate the quality of measurements onboard the ATR-42 research aircraft, a series of intercomparisons between different independent data sets has been accomplished (Fig. 2). The intercomparison results are similar for all four flights. Here we only present time series for one exemplary flight (on 12 July), with cloud presence illustrated by semi-transparent colors. The aerosol inlet is not considered to work properly during cloud passage.

The CPC detection limit is $10^{-4} \mathrm{~cm}^{-3}$ and its measurement uncertainty is $10 \%$ (Wiedensohler et al., 2010) while the Nephelometer detection limit is $2 \mathrm{Mm}^{-1}$ (Doherty et al., 2005) and its uncertainty is $10 \%$ (Anderson et al., 1999; Masonis et al., 2002; Sheridan et al., 2002). Detection limits and uncertaintes on the species measured by the AMS are given in Schmale et al. (2011). The sampling efficiency of the AMS for the POLARCAT campaign has been presented by Schmale et al. (2010, 2011). In rather clean environments, when particle mass concentrations are low, the AMS does not allow to measure size resolved chemical composition. In these cases, the size dependent collection efficiency (decreasing with particle size) cannot be used to correct AMS mass concentrations and is replaced by an experimentally deduced factor of 0.5. In addition, the Pressure Controlled Inlet (PCI) has a transmission efficiency of 0.54. Thus, the total AMS collection efficiency drops to $0.27 \pm 0.17$ and has to be corrected (Schmale et al., 2010). This given AMS uncertainty is very large, however, it does not explain the observed differences between SMPS and AMS calculated mass concentrations. The SMPS has been calibrated and inter-compared with 11 other instruments (Wiedensohler et al., 2010) within the frame of EUSAAR and an error of $3 \%$ was found on the total concentration measurements between all the instruments. This error has been deduced for SMPS laboratory measurements under constant conditions of aerosol generation. However, this does not take into account the uncertainties of SMPS measurements related to 


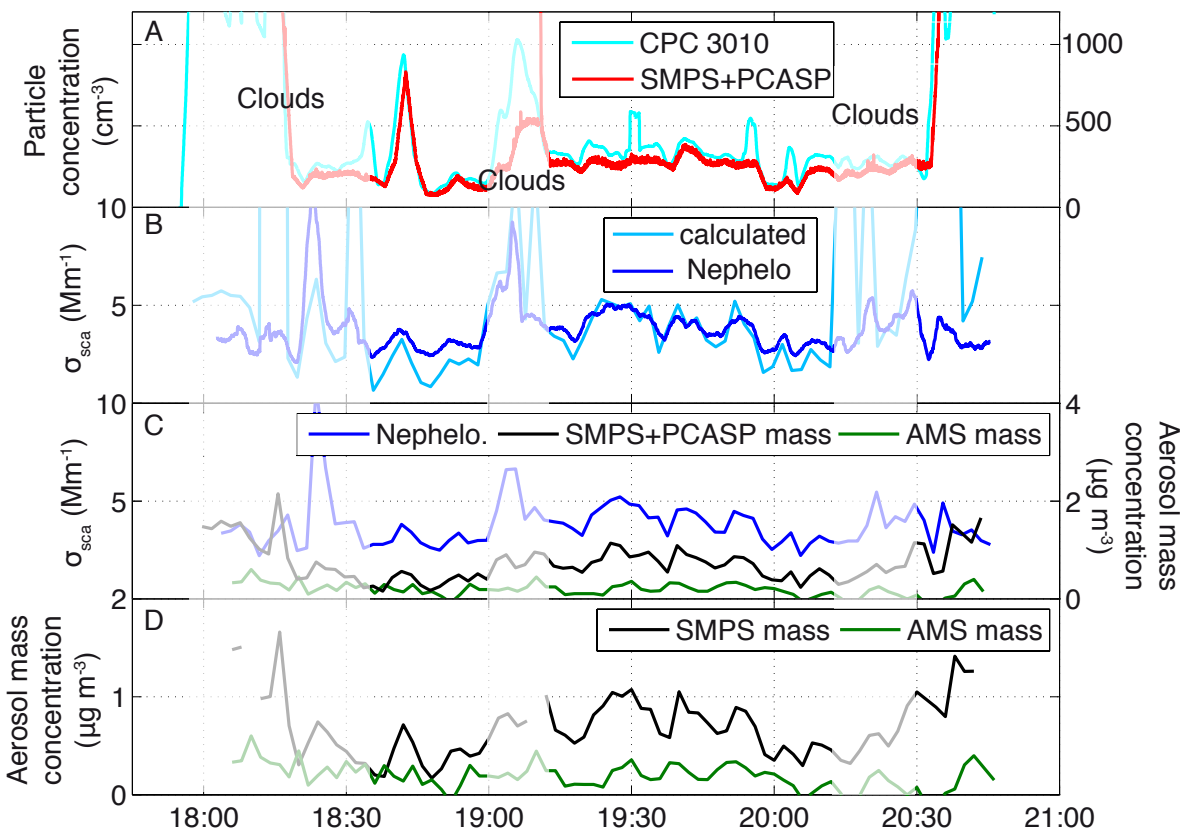

Fig. 2. Intercomparison time series for flight on 12 July: (a) total particle concentrations measured by a CPC 3010 and derived from the SMPS plus PCASP size spectra, (b) aerosol light scattering coefficent $\left(\sigma_{\text {sca }}\right)$ at $450 \mathrm{~nm}$ measured by the nephelometer and derived from SMPS and PCASP aerosol number size distributions using Mie calculations, (c) measured $\sigma_{\text {sca }}$ and aerosol mass determined from the AMS and calculated from SMPS + PCASP number size distributions, and (d) aerosol mass concentrations measured by the AMS (80-1000 nm vacuum aerodynamic diameter) and determined from SMPS size distributions (20-467 nm mobility diameter).

particle concentration fluctuations during single SMPS scans in the atmosphere. A Fourier analysis on the CPC concentrations for all four flights demonstrated that dominating frequencies in the Fourier spectrum are much higher than the frequency of SMPS scans. Therefore, we assume that the SMPS uncertainty due to concentration fluctuations remains reasonably low, however we cannot give quantitative values. Uncertainties have been considered for each type of measurement, based on the confidence interval at $95 \%$ (CI) and the coefficient of variation (COV) as proposed by Doherty et al. (2005). Thus, Nephelometer COV and uncertainty over the 4 flights are $41.3 \%$ and $9.9 \%$, respectively, while SMPS + PCASP total concentration COV and uncertainty are $52.0 \%$ and $12.9 \%$. This does not take into account possible fluctuations of concentrations and also shape of the particle size distribution due to inhomogeneous air masses within single SMPS scans. Finally, CPC total concentration COV and uncertainty are $227 \%$ and $6.4 \%$.

The aerosol particle total number concentrations measured with a CPC and integrated over SMPS and PCASP size spectra were compared (Fig. 2a). SMPS and PCASP number concentration are in agreement $\left(R^{2}=0.57\right)$ within the common size range of $0.11-0.467 \mu \mathrm{m}$ for the 4 flights. Dispersion in linear correlation can be explained by the fixed refractive index (kept constant at 1.59 in our study) and experimental uncertainties of instruments. Since the CPC counts particles beyond $10 \mathrm{~nm}$ while the SMPS + PCASP de- rives particle concentrations for particles larger than $20 \mathrm{~nm}$, the CPC is expected to measure higher concentrations than SMPS + PCASP. In addition, the SMPS scan time of roughly 2 min cannot reproduce CPC variations within one scan. Regular intercomparisons of both SMPS systems (SMPS, NVSMPS) and both GRIMM instruments (OPC, NVOPC) have been performed at ambient temperatures (usually before take-off, without thermodesorption) in order to ensure measurement quality. By means of the thermodenuder system, refractory aerosol number size distributions at $280^{\circ} \mathrm{C}$ are measured with the NVSMPS/NVOPC instruments.

Next to the number concentrations, the light scattering coefficient $\sigma_{\text {sca }}$ directly measured by the TSI nephelometer has been compared to $\sigma_{\text {sca }}$ calculated from the SMPS plus PCASP aerosol number size distributions, thus allowing to cross-check the quality of the SMPS and PCASP data. The calculations of $\sigma_{\text {sca }}$ are performed using a Mie scattering code based on the work of Mätzler (2002) and Bohren and Huffman (1983) and provided by Bond et al. (2006). The code allows calculating $\sigma_{\text {sca }}$ for the specific angular measurement configuration of the TSI nephelometer. The comparison of measured and calculated $\sigma_{\text {sca }}$ is shown in Fig. 2b. Dispersion between measured and calculated $\sigma_{\text {sca }}$ may be explained on the one hand due to a constant refractive index (RI) of 1.59 used for the Mie simulations and on the other hand by the rather poor SMPS time resolution and related variations in particle properties during single SMPS scans. Except during 
Table 1. Slope, interception and correlation coefficient determined from linear regression for flights used for this study between different measurement parameters (as presented in Fig. 2).

\begin{tabular}{|c|c|c|c|c|c|c|c|c|c|c|c|c|}
\hline $\begin{array}{l}\text { Tested time series } \\
\text { Parameters }\end{array}$ & slope & $\begin{array}{c}8 \text { July } \\
\text { intercept. }\end{array}$ & $r^{2}$ & slope & $\begin{array}{l}12 \text { July } \\
\text { intercept. }\end{array}$ & $r^{2}$ & slope & $\begin{array}{c}13 \text { July } \\
\text { intercept. }\end{array}$ & $r^{2}$ & slope & $\begin{array}{c}14 \text { July } \\
\text { intercept. }\end{array}$ & $r^{2}$ \\
\hline CPC 3010/SMPS number concentration & 0.40 & 244.1 & 0.21 & 0.36 & 143.3 & 0.29 & 0.33 & 142.7 & 0.65 & 0.43 & 181.6 & 0.37 \\
\hline$\sigma_{\text {sca }}$ measured and calculated & 1.45 & -1.77 & 0.54 & 1.78 & -2.82 & 0.72 & 1.12 & 0.06 & 0.54 & 1.04 & 0.81 & 0.51 \\
\hline$\sigma_{\text {sca }}$ and SMPS+PCASP aerosol mass & 0.21 & -0.04 & 0.40 & 0.16 & 0.05 & 0.20 & 0.15 & 0.23 & 0.23 & 0.12 & 0.41 & 0.20 \\
\hline$\sigma_{\mathrm{Sca}}$ and AMS aerosol mass & 0.03 & 0.10 & 0.30 & 0.03 & 0.09 & 0.06 & 0.03 & 0.22 & 0.03 & 0.06 & 0.13 & 0.13 \\
\hline SMPS and AMS aerosol mass & 0.31 & -0.01 & 0.29 & 0.17 & 0.12 & 0.09 & 0.41 & 0.02 & 0.31 & 0.24 & 0.19 & 0.10 \\
\hline
\end{tabular}

cloud passages, the correlation is rather good as seen in the linear correlation coefficient (in the range $0.51-0.72$ ) for the four flights. Linear regression calculations, presented in Table 1 (for flights used in this study) confirm the measurements and calculations are well correlated for all considered flights.

Another point is that, $\sigma_{\text {sca }}$ measurements from the nephelometer should be highly correlated to aerosol particle mass, since PSAP absorption measurements suggest that absorption may have contributed only to a very small extent to light extinction. The comparison between $\sigma_{\text {sca }}$ and mass concentration measured with the AMS $(80-1000 \mathrm{~nm}$ vacuum aerodynamic diameter) and calculated from the SMPS plus PCASP size distributions for an arbitrary aerosol particle density of $1.7 \mathrm{~g} \mathrm{~cm}^{-3}$ is presented in Fig. 2c. Linear regression values are indicated in Table 1 for both intercomparisons which clearly demonstrate coherence between the mass (measured by the AMS or derived from SMPS and PCASP distributions) and $\sigma_{\text {sca }}$.

Finally, mass measured by the AMS was compared separately to the mass derived from the SMPS size distributions (Fig. 2d). The PCASP measurements were not considered here in order to compare masses obtained from the AMS (80-1000 $\mathrm{nm}$ vacuum aerodynamic diameter) and from the SMPS size distributions (20-467 nm mobility diameter) within a comparable size range. While the linear regression analysis (Table 1) indicates that both masses are linked, it is clear that the SMPS derived mass exceeds the AMS mass by a factor of 2.6 (in average). This factor can partially be explained by the refractory material (evaporation at temperatures beyond $600^{\circ} \mathrm{C}$ ) within the size distribution, that is excluded in AMS measurements. In addition, due to the small amount of time available for pumping background concentrations out of the AMS vacuum chamber, significant noise levels were found in the AMS signals, thus deteriorating detection limits (Schmale et al., 2011). As a consequence, and since SMPS and PCASP measurements are much better correlated with corresponding independent CPC and nephelometer measurements, we have to be careful in the quantitative interpretation of AMS data within this study.

\section{Classification of sampled air masses}

The Lagrangian particle dispersion model FLEXPART (version 6.2) (Stohl et al., 1998, 2005) was used in a backward mode (Stohl et al., 2003) to characterise the origin of the sampled air masses. The model was initialized for small segments along the flight tracks, i.e. when the aircraft position changed more than $0.20^{\circ}$ in latitude or longitude or $150 \mathrm{~m}$ vertically. Air masses were traced 20 days backward in time. Meteorological analyses from the European Center of Medium-Range Weather Forecast (ECMWF) with $0.5 \times 0.5$ degree resolution were used to drive the model. The primary output of FLEXPART backward calculations is the potential emission sensitivity (PES). Column-integrated PES values were used here mainly to characterise the origin and transport pathways of the sampled air masses. Furthermore, the lowest model layer $(0-100 \mathrm{~m})$ is called the footprint PES (FPES). When multiplying the FPES values with CO emissions (e.g. from anthropogenic and fire sources), $\mathrm{CO}$ source contribution maps and $\mathrm{CO}$ tracer mixing ratios at the aircraft location can be calculated. The integration of the footprint over continents leads to an estimation of the continent contribution to the $\mathrm{CO}$ enhancement. Using the column-integrated PES, the footprint PES (FPES), and the CO source apportionment, four predominant air mass origins were identified for the entire measurement campaign:

1. Europe, corresponding to Iceland, Great Britain, Scandinavia and western Russia,

2. Asia, including Siberia and northern China where many boreal forest fires took place,

3. the Arctic, and

4. North America, representing the closest pollution source region from Greenland.

This study focuses on air masses originating from North America, and especially from two source regions: (i) Canadian boreal forest fires and, (ii) American anthropogenic pollution. 13 separate flight periods related to air masses transported from North America were identified. More specifically, 12 periods could be related to the boreal forest fire origins, whereas only 1 period represents anthropogenic 

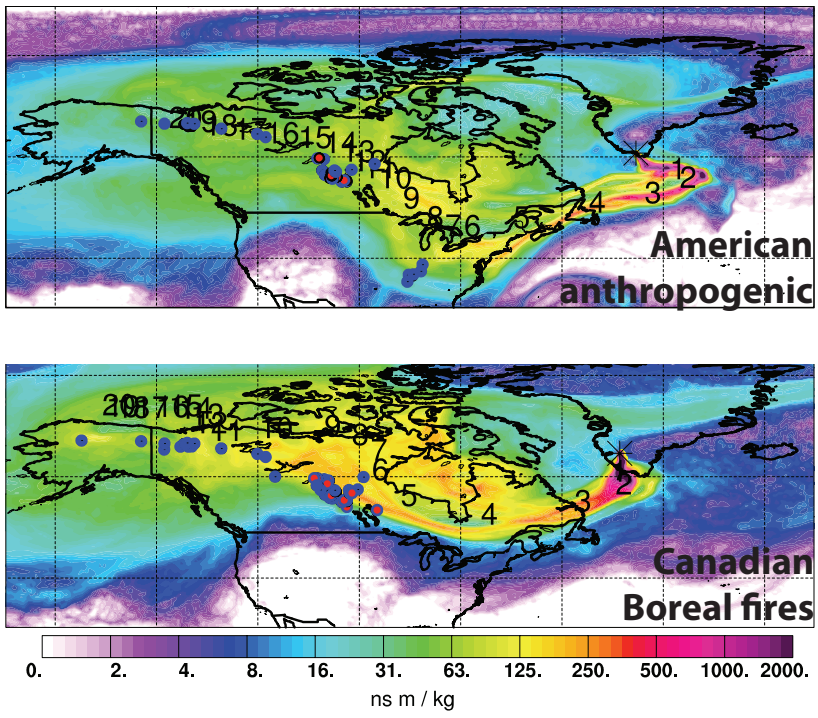

Fig. 3. FLEXPART North American column-integrated potential emissions sensitivities (PES). Examples for American anthropogenic (AN) and Canadian boreal fire (BF) origins are presented in the upper and lower panel, respectively. The red dots indicate forest fires while the blue dots express other fires (mostly agricultural), both detected by MODIS. Numbers on the two panels indicate the daily retroplume centroid positions, as FLEXPART calculates back in time. Values are plotted in a logarithmic scale.

sources. In order to illustrate differences between these two North American air masses, Fig. 3 presents the FLEXPART column-integrated PES maps for the two origins. In addition, Fig. 4 shows the continental source apportionment determined by the FLEXPART model for the four flights when air masses from North America have been sampled. Forest fires and fires from other sources (mostly agricultural fires) detected by the satellite-based spectro-radiometer MODIS (Moderate Resolution Imaging Spectro-radiometer) and treated by the algorithms illustrated in Giglio et al. (2003), are represented by red and blue dots respectively if the PES value on the day of the fire detection was larger than $8 \mathrm{~ns} \mathrm{~m} \mathrm{~kg}{ }^{-1}$. CO enhancements measured on the ATR-42 aircraft and calculated by FLEXPART for the 13 flight periods related to North American air masses are presented in Table 2. Discrepancies between both values may appear when source strength is not well determined by the model, e.g. for the first periods on 8 July. In addition, removal processes such as wet deposition are not considered in the model.

\section{Results and discussions}

\subsection{CO concentrations}

During summer, the tropospheric CO background mixing ratios in the northern hemisphere are on the order of $90 \mathrm{ppbv}$ (Real et al., 2007). CO enhancements over the background concentration were detected using $\mathrm{CO}$ mixing ratio time series (as seen in Fig. 4). Detected peaks in measured $\mathrm{CO}$ enhancements were associated with air mass origins retrived from FLEXPART PES, FPES and source apportionment analyses. Polluted North American air masses were encountered during 4 of the 12 scientific flight missions on 8, 12 (PM), 13 and 14 (PM) of July. For these four flights, we identified 13 periods when air masses originated from the North American continent. In more detail, we found 12 periods related to Canadian boreal forest fires as well as 1 time window with air masses of American anthropogenic origin. Enhanced CO mixing ratios (beyond background) are presented in Table 2. On its own, CO enhancement levels cannot explain air mass origins. It is important to note that, during the whole campaign, $\mathrm{CO}$ enhancement never reached very high levels when compared to measurements in biomass burning ( $\triangle \mathrm{CO}=80 \mathrm{ppbv})$ and anthropogenic pollution ( $\triangle \mathrm{CO}=60 \mathrm{ppbv}$ ) plumes performed by Paris et al. (2010). Using the FLEXPART fire tracer age spectra described in Stohl et al. (2005) as well as the FLEXPART biomass burning potential source contributions (Stohl et al., 2007), the age of each North American air mass and the related sources strength were estimated. Mean age values are given in Table 2.

The two relationships (not shown) between aerosol number concentration normalised by $\triangle \mathrm{CO}$ as a function of the FLEXPART plume ages and as a function of $\triangle \mathrm{CO}$ for the studied NA air masses were found to be weakly correlated $\left(R^{2}=0.42\right.$ and 0.23$)$ with highly scattered data points and significant error bars, probably due to aerosol cloud scavenging with different strength. In the following section, the aerosol chemical properties measured during the 4 flights of interest, and more specifically during the selected time windows, are investigated.

\subsection{Aerosol chemical composition}

To characterise the aerosol particle sources, the ratio between particulate organic matter and particulate sulphate abundances can give an indication about the source type. For anthropogenic sources, i.e. fossil fuel combustion from North America, high sulphate concentrations are expected (Heald et al., 2006; Singh et al., 2010; Schmale et al., 2011), whereas large concentrations of organics and low concentration of sulphate are expected for Canadian boreal forest fire sources (Andreae and Merlet, 2001; Schmale et al., 2011). Figure 5 presents stacked time series of the concentrations of sulphate, organics, and NVSMPS/NVOPC derived refractory particulate matter observed during the four flights of interest (ATR-42 flights on 8, 12, 13 and 14 July 2008). The 13 time windows for North American air masses are highlighted by two different colours (red for Canadian boreal forest fires and yellow for American pollution). Periods when the aircraft sampled inside clouds shown in semitransparent colors, have been excluded from the analysis due 


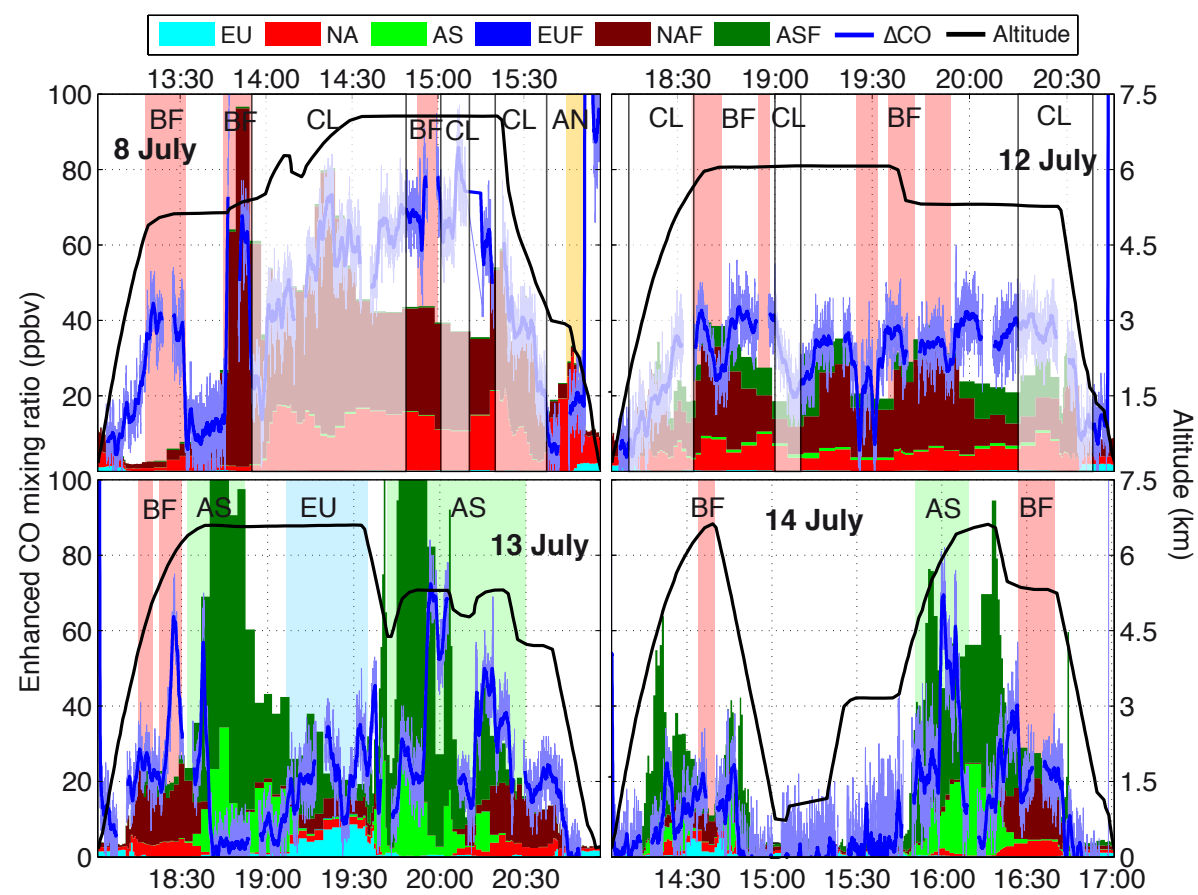

Fig. 4. Time series of ATR-42 in-situ measurements of enhanced carbon monoxide mixing ratio over background ( $\Delta \mathrm{CO})$, along the flight tracks (flights on 8,12, 13 and 14 July). The anthropogenic continental source apportionments of CO enhancements over background from the FLEXPART backward simulations are shown in different colors for Europe (EU), Asia (AS) and North America (NA). Likewise fire contributions from the three continents are indicated with EUF, ASF and NAF. Air masses selected for this study are highlighted in red for Canadian boreal fires ("BF") and yellow for anthropogenic ("AN") air masses. Asian ("AS", green) and European ("EU", blue) air masses, discussed in Schmale et al. (2011), are also indicated. Cloudy periods ("CL", in white) are indicated in white with black frame.

Table 2. Start and end time of the 13 selected time periods. In addition, mean concentrations of $\Delta C O$ and FLEXPART $\Delta C O$ are presented as well as the mean FLEXPART fire tracer age.

\begin{tabular}{|c|c|c|c|c|c|c|}
\hline Flight date & Origin & $\begin{array}{l}\text { Start time } \\
\text { (HH:MM) }\end{array}$ & $\begin{array}{l}\text { End Time } \\
\text { (HH:MM) }\end{array}$ & $\begin{array}{c}\text { Measured } \Delta C O \\
(\text { ppbv })\end{array}$ & $\begin{array}{c}\text { FLEXPART } \Delta \text { CO } \\
(\text { ppbv })\end{array}$ & $\begin{array}{c}\text { Mean FLEXPART } \\
\text { age (days) }\end{array}$ \\
\hline \multirow{4}{*}{8 July } & $\mathrm{BF}$ & $13: 18$ & $13: 32$ & 37.1 & 4.8 & 11.4 \\
\hline & $\mathrm{BF}$ & $13: 45$ & $13: 55$ & 51.2 & 62.5 & 6.4 \\
\hline & $\mathrm{BF}$ & $14: 53$ & $15: 00$ & 70.4 & 43.8 & 8.2 \\
\hline & AN & $15: 45$ & $15: 52$ & 23.1 & 22.2 & 8.2 \\
\hline \multirow{5}{*}{12 July } & $\mathrm{BF}$ & $18: 36$ & $18: 46$ & 32.3 & 39.0 & 11.7 \\
\hline & $\mathrm{BF}$ & $18: 55$ & $18: 59$ & 41.7 & 27.5 & 11.6 \\
\hline & $\mathrm{BF}$ & $19: 25$ & $19: 32$ & 18.1 & 20.6 & 12.4 \\
\hline & $\mathrm{BF}$ & $19: 35$ & $19: 42$ & 35.3 & 28.8 & 12.0 \\
\hline & $\mathrm{BF}$ & $19: 46$ & $19: 54$ & 32.5 & 38.7 & 12.1 \\
\hline \multirow{2}{*}{13 July } & $\mathrm{BF}$ & $18: 15$ & $18: 20$ & 24.7 & 24.1 & 13.0 \\
\hline & $\mathrm{BF}$ & $18: 22$ & $18: 30$ & 38.6 & 22.1 & 13.4 \\
\hline \multirow{2}{*}{14 July } & $\mathrm{BF}$ & $14: 34$ & $14: 40$ & 21.1 & 15.1 & 13.0 \\
\hline & $\mathrm{BF}$ & $16: 27$ & $16: 40$ & 18.2 & 27.6 & 13.4 \\
\hline
\end{tabular}




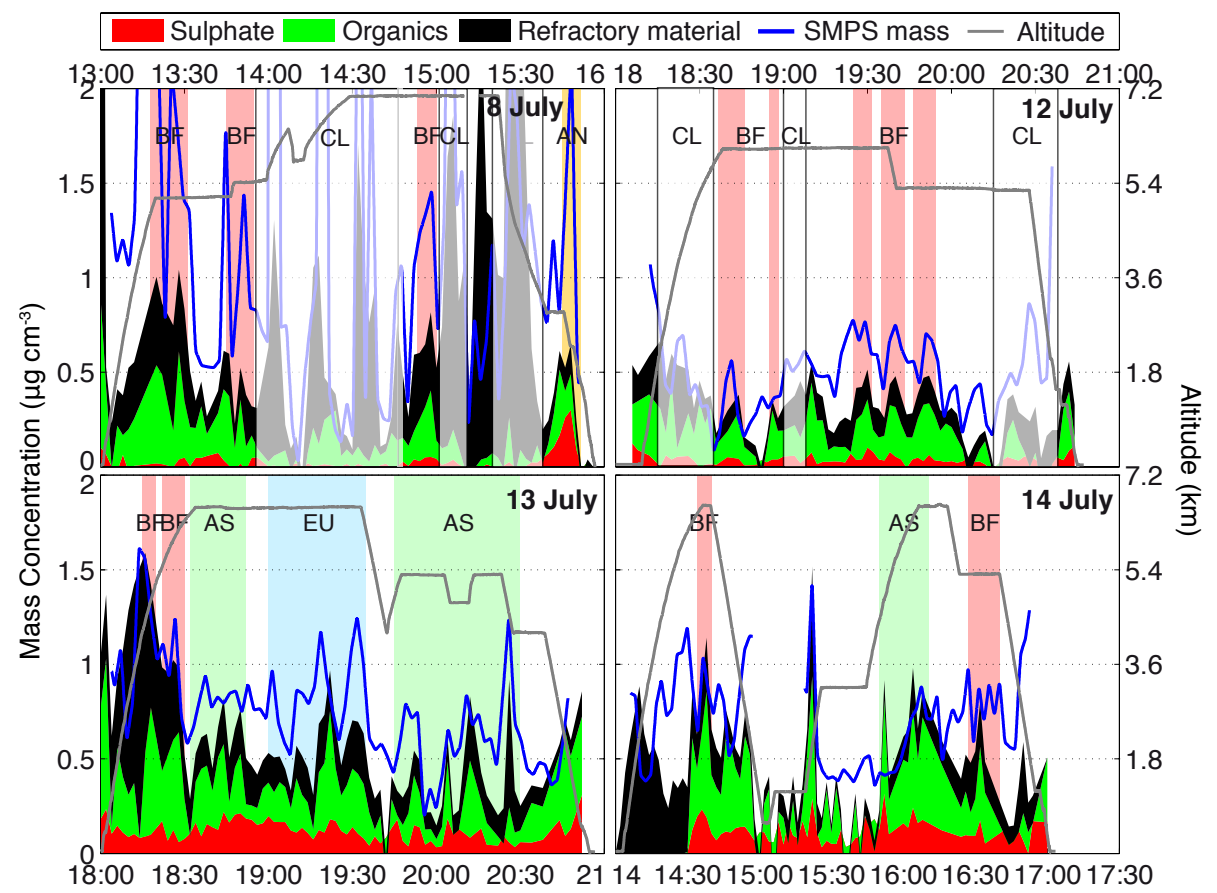

Fig. 5. Stacked aerosol mass concentrations in $\mu \mathrm{g} \mathrm{m} \mathrm{m}^{-3}$ for sulphate (red), organics (green), and refractory material (black). Air mass origins determined with FLEXPART integrated-column PES, FPES and source apportionment are noted with AN for North-American anthropogenic emissions, BF for Canadian boreal forest fires, AS for Asia and EU for Europe, while cloud presence is indicated with "CL". The blue line represents the estimated mass of particulate material at ambient temperature calculated from SMPS aerosol volume size distributions and a density of $1.7 \mathrm{~g} \mathrm{~cm}^{-3}$.

to sampling errors of the aerosol inlet. All other peaks in the measured mass concentrations are due to air masses from source regions other than North America (Asia and Europe, as highlighted in the 13 July and 14 July time series, see also Schmale et al., 2011). The analysis of these air masses is not within the scope of this study. In addition, the total particulate mass estimated from SMPS/OPC measurements at ambient temperature is represented in blue. Furthermore, Fig. 6 illustrates for the four flights relevant for North American air masses, averaged amounts of volatile and refractory aerosol mass concentrations as well as averaged mass concentrations of particulate sulphate and organics (two upper charts for each flight). In addition, AMS mass (organics, sulphate) and SMPS + PCASP mass data (refractory, nonrefractory) are then merged under the constraint that AMS mass concentrations were adjusted to match total mass calculated from the size distributions. Air mass origins, according to FLEXPART, are indicated on the $\mathrm{x}$-axis. For air masses from North-American anthropogenic sources (AN) and Canadian boreal forest fires (BF), the chemical compositions agreed well with those expected above, thus, confirming the choice of the time windows.

\subsection{Aerosol number size distributions}

To study aerosol physical properties, aerosol number size distributions measured during the diagnosed time periods were fitted with lognormal distributions. The lognormal fitting method was based on three to four aerosol particle modes. According to Schwarz et al. (2008) and Hosseini et al. (2010), fresh soot particles from biomass burning and urban pollution are limited in size to diameters below $300 \mathrm{~nm}$. However, soot particles can be coated with other atmospheric components such as organics and sulphate (Bond et al., 2006). Previous studies, (Fiebig et al., 2003; Petzold et al., 2007) showed measurements of aerosol physicochemical properties, over Germany and Central Europe, of aged North American biomass burning air masses. Both studies highlighted large mean diameters between 200 and $340 \mathrm{~nm}$ for the accumulation mode, for air mass ages of 6 to 9 days. In these studies, air mass ages were also estimated using FLEXPART in Petzold et al. (2007) and through a theoretical approach demonstrated by Reid et al. (1998) and used in Fiebig et al. (2003).

Figure 7 presents the observed and fitted aerosol number size distributions for air masses originating from North America for each flight considered in this study. In order to fit the observed number size distributions, the log-normal parameterisation is utilizing three to four modes, to adequately 


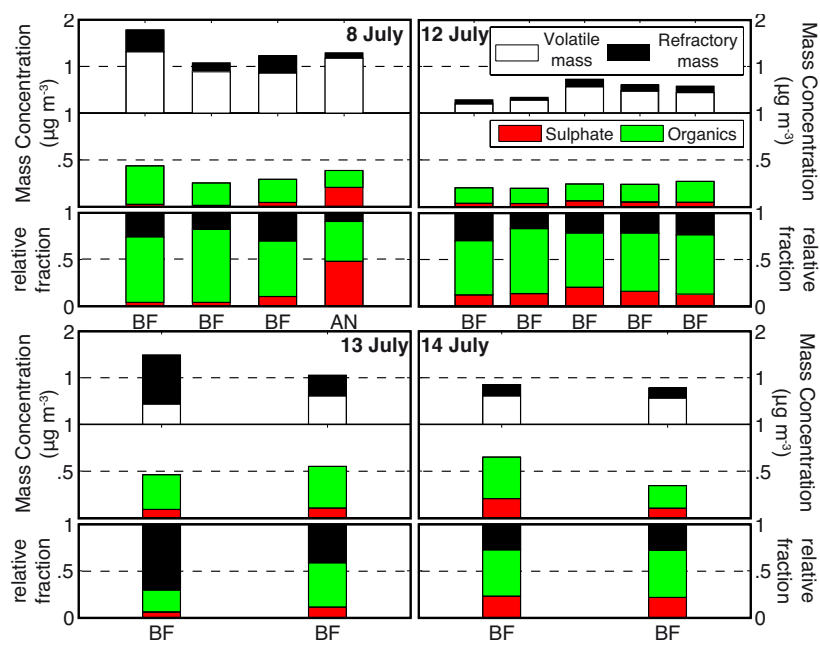

Fig. 6. Aerosol chemical composition for selected time windows. For each flight, the top panel presents the aerosol volatile and refractory volume fractions. Middle panels indicate the amount of organics and sulphate measured by the AMS, while the bottom panels compile top and middle panels in order to obtain the partitioning of refractory mass, organics and sulphate (Air mass origins determined with FLEXPART integrated-column PES are noted with AN for North-American anthropogenic and BF for Canadian boreal forest fires).

reproduce the observations. The fit of four modes was used to yield an improved approximation of the observed data, as compared to using three modes, thus, leading to the introduction of an "intermediate" mode between the Aitken and accumulation modes. The different log-normal parameters (i.e. number concentrations $n_{i}$, the standard deviation $\sigma_{i}$, and the mean diameter $d_{\mathrm{m} i}$ where $i$ is the mode number) are given in Table 3 .

A major result regarding the aerosol number size distributions from Canadian boreal forest fires (BF) is that for 9 out of 12 plume cases, relatively high Aitken mode particle concentrations (as compared to the campaign mean concentrations) were observed. For these nine plumes Aitken mode concentrations exceeded $93 \mathrm{~cm}^{-3}$, with geometric mean diameter and standard deviation of $45.9 \pm 8.0 \mathrm{~nm}$ and $1.41 \pm 0.18$, respectively. These values are comparable to the parameters reported by Hosseini et al. (2010) who found average size distributions with mean diameters between 25 and $52 \mathrm{~nm}$ and with standard deviations between 1.58 and 1.76 in laboratory studies of biomass burning aerosol particles. This would mean that these particles from boreal forest fires did not grow to a significant extent during the 7-13 days of transport (meaning that particle condensational growth (coating) has been rather negligible). Alternatively, coagulation proceeded at a rate proportional to the square of the particle concentration (Hinds, 1999). Since the aerosol number and mass concentrations in North American pollution plumes measured during the POLARCAT campaign are not as high

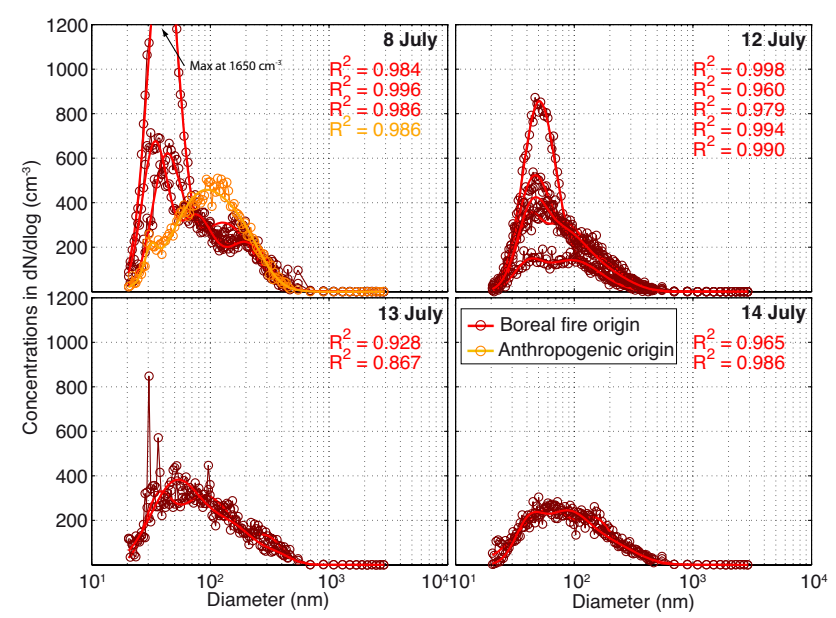

Fig. 7. Log-normal fitted aerosol number size distributions (solid line) and measurements (solid line with symbol) for the selected time windows of the 4 respective flights.

as the ones measured during other campaigns (Petzold et al., 2007; Fiebig et al., 2003), the coagulation process is expected to be slower in plumes studied here, implicating an increased Aitken mode lifetime.

A comparison of aerosol number size distributions measured during the above mentioned other studies with those determined within POLARCAT (this study, Fig. 7) is presented in Fig. 8a, while Fig. 8b shows the aerosol number size distributions normalised with respective $\mathrm{CO}$ enhancements (only provided by Petzold et al., 2007). Concerning the accumulation mode, measured concentrations and mean diameters were lower during POLARCAT than those reported by Fiebig et al. (2003) and Petzold et al. (2007). Normalisation with $\triangle \mathrm{CO}$ demonstrates that the Aitken mode observed during POLARCAT is comparable to what has been measured by Petzold et al. (2007) which is obviously not the case for the accumulation modes. The differences between the number size distributions, principally concerning the accumulation mode concentrations, might be explained by a cleansing of accumulation mode particles due to cloud scavenging. To investigate this, we used the HYSPLIT on-line version of the Lagrangian back-trajectory model (Draxler and Rolph, 2010; Rolph, 2010) that provides, in addition to the back-trajectory coordinates, the relative humidity $(\mathrm{RH})$ along the trajectories. The back-trajectories for 8 July are presented in Fig. 9 where RH, altitude, and the ECMWF total column precipitation are colour coded, respectively. Fire hot spots from MODIS are highlighted by red squares. It appears that almost all 12 air masses containing particles from forest fires experienced relative humidities near $100 \%$ coupled to important amounts of precipitation after passing over the fire regions. This leads to the conclusion that in most of the cases, the accumulation mode is likely to have been scavenged by cloud processes. 
Table 3. Log-normally fitted size distribution parameters for the 13 selected time windows.

\begin{tabular}{|c|c|c|c|c|c|c|c|c|c|c|c|c|c|}
\hline \multirow[t]{2}{*}{ Flight date } & \multirow[t]{2}{*}{ Origin } & \multicolumn{3}{|c|}{ Aitken mode $5 \geq d_{\mathrm{m} 1}<90$} & \multicolumn{3}{|c|}{ Intermediate mode $60 \geq d_{\mathrm{m} 2}<300$} & \multicolumn{3}{|c|}{ Accumulation mode $150 \geq d_{\mathrm{m} 3}<800$} & \multicolumn{3}{|c|}{ Coarse mode $800 \geq d_{\mathrm{m} 4}<3000$} \\
\hline & & $n_{1}\left(\mathrm{~cm}^{-3}\right)$ & $\sigma_{1}$ & $d_{m 1}(\mathrm{~nm})$ & $n_{2}\left(\mathrm{~cm}^{-3}\right)$ & $\sigma_{2}$ & $d_{\mathrm{m} 2}(\mathrm{~nm})$ & $n_{3}\left(\mathrm{~cm}^{-3}\right)$ & $\sigma_{3}$ & $d_{\mathrm{m} 3}(\mathrm{~nm})$ & $n_{4}\left(\mathrm{~cm}^{-3}\right)$ & $\sigma_{4}$ & $d_{\mathrm{m} 4}(\mathrm{~nm})$ \\
\hline \multirow{4}{*}{8 July } & Can. BF & 125 & 1.29 & 42 & 173 & 1.77 & 75 & 67 & 1.43 & 230 & 1.34 & 1.56 & 800 \\
\hline & Can. BF & 445 & 1.31 & 38 & 117 & 1.39 & 60 & 137 & 1.55 & 156 & 0.37 & 1.99 & 806 \\
\hline & Can. BF & 156 & 1.25 & 33 & 129 & 1.41 & 65 & 109 & 1.56 & 182 & 0.65 & 1.42 & 800 \\
\hline & Anth. NA & 58 & 1.41 & 40 & - & - & - & 294 & 1.77 & 113 & 0.07 & 1.30 & 2000 \\
\hline \multirow{5}{*}{12 July } & Can. BF & 293 & 1.38 & 50 & 55 & 1.61 & 115 & 2.23 & 1.30 & 414 & 0.09 & 1.69 & 2029 \\
\hline & Can. BF & 31 & 1.31 & 40 & 83 & 1.72 & 96 & 0.02 & 1.30 & 800 & 0.10 & 1.11 & 1334 \\
\hline & Can. BF & 93 & 1.33 & 46 & - & - & - & 158 & 1.77 & 109 & 0.54 & 1.77 & 800 \\
\hline & Can. BF & 162 & 1.38 & 46 & - & - & - & 129 & 1.79 & 112 & 0.21 & 1.97 & 1139 \\
\hline & Can. BF & 113 & 1.36 & 46 & - & - & - & 144 & 1.80 & 101 & 0.40 & 1.99 & 800 \\
\hline \multirow{2}{*}{13 July } & Can. BF & 62 & 1.28 & 36 & 199 & 1.80 & 90 & 29 & 1.33 & 313 & 0.14 & 1.58 & 1338 \\
\hline & Can. BF & 195 & 1.63 & 51 & 87 & 1.63 & 150 & 8.4 & 1.30 & 379 & 0.15 & 1.42 & 1498 \\
\hline \multirow{2}{*}{14 July } & Can. BF & 160 & 1.80 & 61 & 39 & 1.30 & 160 & 18 & 1.32 & 299 & 0.64 & 1.37 & 800 \\
\hline & Can. BF & 45 & 1.30 & 41 & 100 & 1.55 & 81 & 56 & 1.70 & 186 & 0.14 & 1.33 & 1743 \\
\hline
\end{tabular}

Table 4. Various parameters calculated from the analysis of ambient and elevated temperature size distributions (accumulation mode modal diameter, $F_{\text {conc, ac }}, F_{\text {volatile, ac }}, F_{\text {volatile }}$, ratio of refractory particles with diameter larger than $10 \mathrm{~nm}$, ratio of volatile particles with diameter larger than $\left.90 \mathrm{~nm}, \Delta \mathrm{CO}, \sigma_{\mathrm{abs}}\right)$ classified as a function of $F_{\text {diam, ac }}$.

\begin{tabular}{llrrrrrrr}
\hline Classification & Origin & $\begin{array}{r}\text { accumulation mode } \\
\text { mean diameter }(\mathrm{nm})\end{array}$ & $\begin{array}{r}F_{\text {diam,ac }} \\
(\%)\end{array}$ & $\begin{array}{r}F_{\text {conc, } D>90 \mathrm{~nm}} \\
(\%)\end{array}$ & $\begin{array}{r}F_{\text {conc }} \\
(\%)\end{array}$ & $\begin{array}{r}F_{\text {volatile }} \\
(\%)\end{array}$ & $\begin{array}{r}\Delta \mathrm{CO} \\
(\mathrm{ppbv})\end{array}$ & $\begin{array}{r}\sigma_{\text {abs }} \\
\left(\mathrm{Mm}^{-1}\right)\end{array}$ \\
\hline$F_{\text {diam,ac }}<30 \%$ & BF & 125 & 20.5 & 63.7 & 94 & 72.1 & 37.3 & $*$ \\
$30 \%<F_{\text {diam,ac }}$ & BF & 128 & 43.6 & 31.7 & 93 & 75.7 & 33.0 & $0.22 \pm 0.20$ \\
$70 \%<F_{\text {diam,ac }}$ & AN & 113 & 71.8 & 9.8 & $* *$ & 94.6 & 23.1 & $0.32 \pm 0.16$ \\
\hline
\end{tabular}

* No value here since most of the measurements were below the detection limit of $0.175 \mathrm{Mm}^{-1}$.

* Ratio larger $100 \%$ potentially due tu SMPS and VSMPS variabilities related to 2 min scan times.

\subsection{Refractory aerosol particles}

Size distribution measurements at ambient and elevated $\left(280^{\circ} \mathrm{C}\right)$ temperature allows to determine five parameters: (i) the total aerosol volatile volume fraction $\left(F_{\text {volatile }}\right)$, (ii) the accumulation mode volatile volume fraction $\left(F_{\text {volatile, } D>90 \mathrm{~nm}}\right)$, (iii) the fraction of accumulation mode modal diameter decrease $\left(F_{\text {diam,ac }}\right)$, (iv) the number fraction of accumulation mode volatile particles $\left(F_{\mathrm{conc}} D>90 \mathrm{~nm}\right)$, and $(\mathrm{v})$ the number fraction of refractory particles $\left(F_{\text {conc }}\right)$. These five parameters are calculated as follows:

$F_{\text {volatile }}=\frac{V_{\mathrm{ambient}}-V_{280^{\circ} \mathrm{C}}}{V_{\mathrm{ambient}}}$

where, $V_{\text {ambient }}$ and $V_{280^{\circ} \mathrm{C}}$ denote total aerosol volume at ambient temperature and at $280^{\circ} \mathrm{C}$, respectively.

$F_{\text {volatile }, D>90 \mathrm{~nm}}=\frac{V_{\text {ambient }, D>90 \mathrm{~nm}}-V_{280}{ }^{\circ} \mathrm{C}, D>90 \mathrm{~nm}}{V_{\text {ambient, } D>90 \mathrm{~nm}}}$

where $V_{\text {ambient, } D>90 \mathrm{~nm}}$ and $V_{280}{ }^{\circ} \mathrm{C}, D>90 \mathrm{~nm}$ denote accumulation mode aerosol volume (for particles with diameters larger than $90 \mathrm{~nm}$ ) at ambient temperature and at $280^{\circ} \mathrm{C}$, respectively.

$F_{\text {diam }, \mathrm{ac}}=\frac{D_{\text {ambient }, \mathrm{ac}}-D_{280^{\circ} \mathrm{C}, \mathrm{ac}}}{D_{\text {ambient, } \mathrm{ac}}}$

with, $D_{\text {ambient,ac }}$ and $D_{280}{ }^{\circ} \mathrm{C}$,ac are corresponding to the aerosol accumulation mode modal mean diameter at ambient temperature and at $280^{\circ} \mathrm{C}$, respectively.

$$
F_{\text {conc }, D>90 \mathrm{~nm}}=\frac{N_{\text {ambient, } D>90 \mathrm{~nm}}-N_{280}{ }^{\circ} \mathrm{C}, D>90 \mathrm{~nm}}{N_{\text {ambient }, D>90 \mathrm{~nm}}}
$$

with $N_{\text {ambient }, D>90 \mathrm{~nm}}$ and $N_{280}{ }^{\circ} \mathrm{C}, D>90 \mathrm{~nm}$ are corresponding to the aerosol accumulation mode concentration (for particles with diameters larger than $90 \mathrm{~nm}$ ) at ambient temperature and at $280^{\circ} \mathrm{C}$, respectively.

$F_{\text {conc }}=\frac{N_{280^{\circ} \mathrm{C}}}{N_{\text {ambient }}}$

with $N_{\text {ambient }}$ and $N_{280}{ }^{\circ} \mathrm{C}$ are corresponding to the total aerosol concentration at ambient temperature and at $280^{\circ} \mathrm{C}$, respectively.

The three accumulation mode related parameters are presenting evidence on the state of mixture of Aitken and accumulation mode particles and to what extent accumulation mode aerosol particles may have been coated. Therein, 


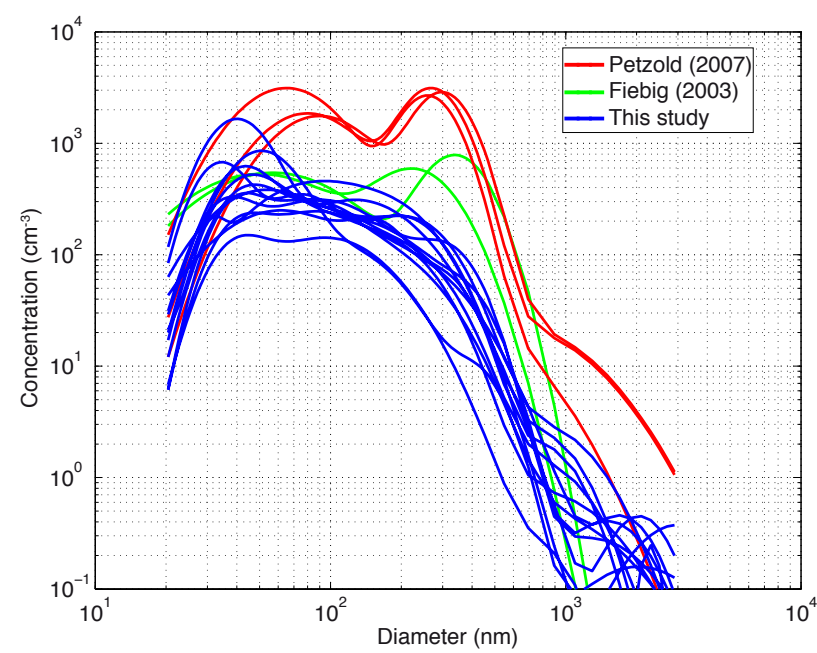

Fig. 8a. Fitted aerosol number size distributions of air masses originating from North-American boreal forest fires measured over Central Europe (Petzold et al., 2007) in solid red line, Germany (Fiebig et al., 2003) in solid green line, and Greenland (this study) in solid blue line.

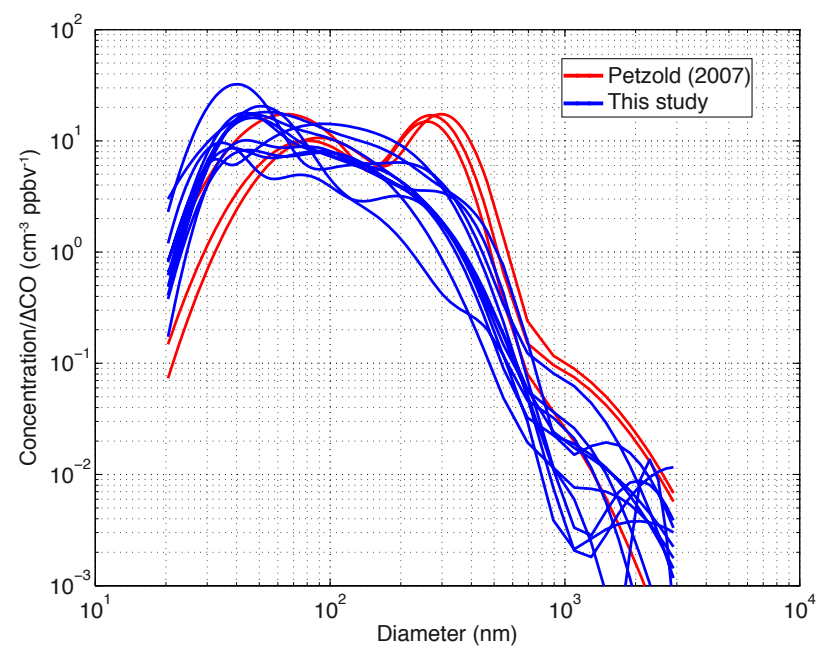

Fig. 8b. Fitted aerosol number size distributions normalised by $\mathrm{CO}$ enhancement for air masses originating from North-American boreal forest fires measured over Central Europe (Petzold et al., 2007) in solid red line, and Greenland (this study) in solid blue line.

$F_{\text {volatile, } D>90 \mathrm{~nm}}$ is corresponding to the amount of volatile material that is desorbed at $280^{\circ} \mathrm{C}$, from the accumulation mode, while $F_{\text {conc, } D>90 \mathrm{~nm}}$ indicates the number of particles not remaining in the accumulation mode due to volatilization, and finally $F_{\text {diam,ac }}$ is a measure for the shift in the accumulation mode modal diameter, when comparing refractory to ambient accumulation mode. Thus, high fractions of $F_{\text {volatile, } D>90 \mathrm{~nm}}, F_{\text {conc, } D>90 \mathrm{~nm}}$ and $F_{\text {diam,ac }}$, indicate highly volatile aerosol particulate matter, either emitted by the source region or due to coating with rather volatile ma-

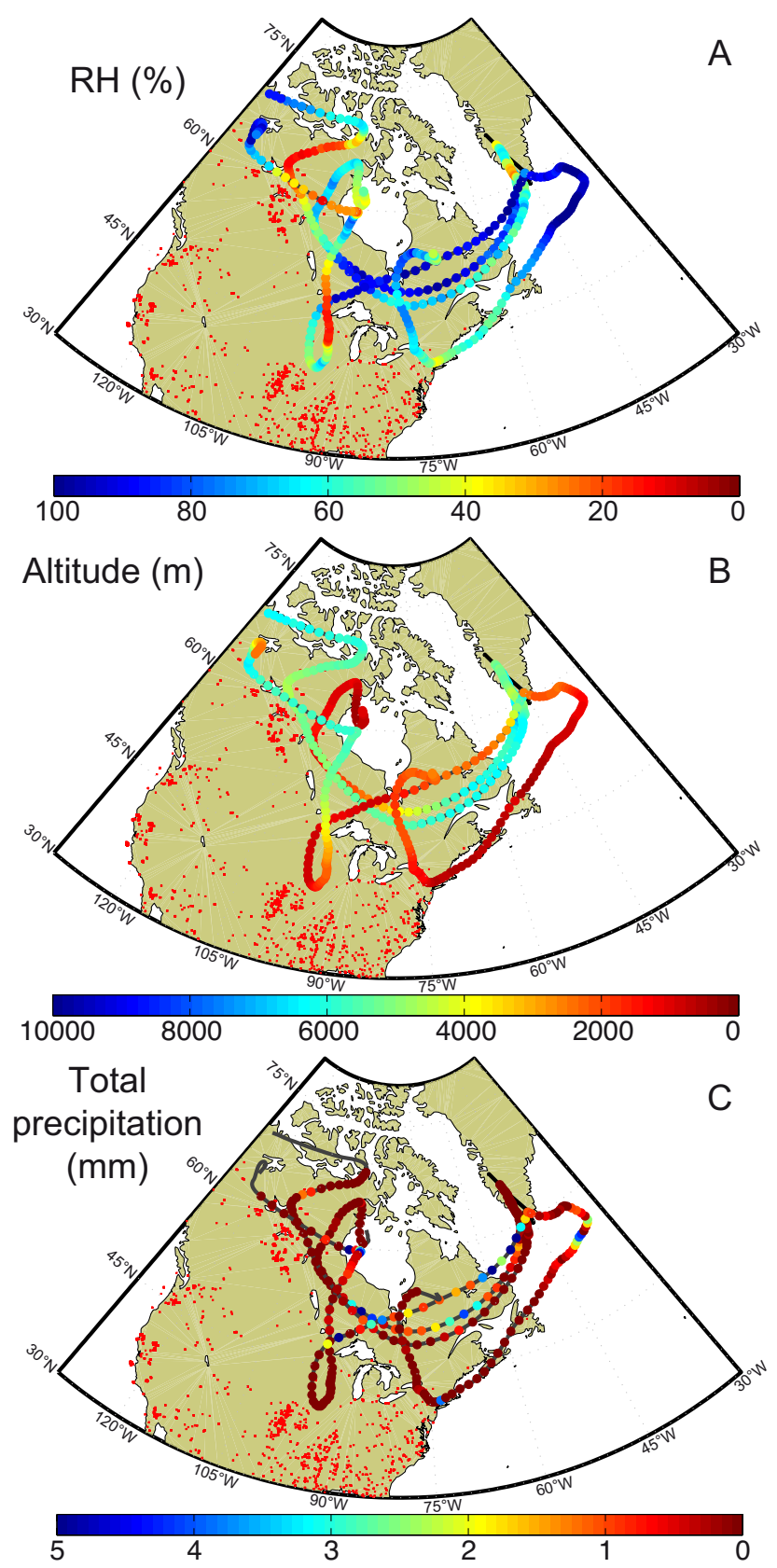

Fig. 9. HYSPLIT back-trajectories for the four forest fire time windows on 8 July. (a) Relative humidity (RH), (b) altitude and (c) total precipitation are colour coded along the back-trajectories. Red dots symbolize fire spots from MODIS.

terial. $F_{\text {diam,ac }}$ was used to classify the ambient and elevated temperature size distributions of selected North American air masses in 3 separate groups (Fig. 10). It turns out that Fig. 10a and $\mathrm{b}$ are both related to $\mathrm{BF}$ air masses classified in terms of $F_{\text {diam,ac }}$ (above or below $30 \%$ ), whereas Fig. 10c constitutes the AN air mass. All the above introduced parameters related to the 3 groups are given in Table 4 . The 

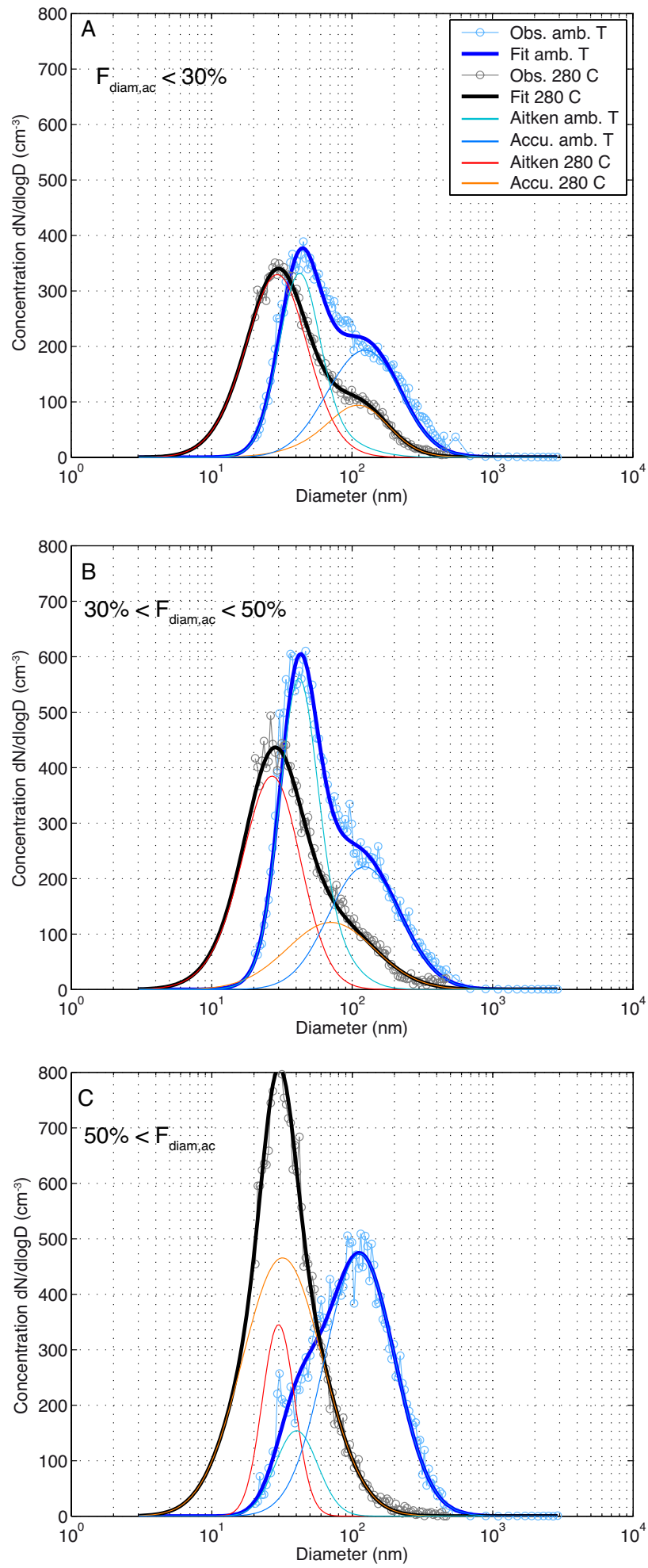

Fig. 10. Ambient and refractory mean aerosol number size distributions (in blue and black, respectively) observed (solid line with circles) and fitted (solid line) for the 3 groups classified regarding their $F_{\text {diam,ac }}$ values. Aitken and accumulation modes are also indicated. shift in accumulation mode modal diameter is most important for AN air mass, thus illustrating that the corresponding accumulation mode particles are basically volatile at $280^{\circ} \mathrm{C}$ (95\% volatility in volume, in other words only $5 \%$ of the accumulation mode particle volume is refractory material). In contrast, the fraction of refractory accumulation mode particle volume within BF air masses is on average 25-30\%. The fact that accumulation mode modal diameter is still seen in the refractory size spectra of BF air masses, means that the accumulation mode is composed of a smaller fraction of refractory particles and another larger fraction of rather volatile particles, which indicates an external mixture of (possibly internally mixed) particles. When comparing number concentrations of all refractory particles over the respective concentrations at ambient temperature (see $F_{\text {conc }}$ in Table 4) we conclude that in number more than $93 \%$ of the particles are composed of partly non volatile material which can be $\mathrm{BC}$, but also less volatile organic material (at $280^{\circ} \mathrm{C}$ ). This finding is true for both categories, namely $\mathrm{AN}$ as well as BF air mass particles. Surprisingly, the mean light absorption coefficent (mostly related to black carbon) is slightly higher for the anthropogenic air mass as compared to boreal fire air masses. However, because of the low values (close to the detection limit) of measured absorption coefficients, this result has to be considered with caution.

\section{Conclusions}

In this study, we have presented in-situ aerosol and gas phase measurements performed during the POLARCATFrance summer campaign using the ATR-42 research aircraft based at Kangerlussuaq, Greenland. Measurements of aerosol number size distributions, chemical composition, aerosol light absorption coefficient, aerosol refractory properties as well as carbon monoxide concentrations were analysed. In general CO enhancement peaks over background were used to identify pollution plumes. Subsequently, these plumes were associated with air mass origins retrieved from FLEXPART PES, FPES and source apportionment analyses in order to classify air mass origins. This study concentrates entirely on air masses with clearly identified North American origins. For the time periods when air masses originated from the NA continent, aerosol number size distributions were averaged and subsequently fitted assuming three or four aerosol modes. Focusing on the air masses representing Canadian boreal forest fires $(\mathrm{BF})$, the mean aerosol particle concentrations appear to decrease exponentially with respect to plume life time after emission and thus, correlate with the decrease of $\mathrm{CO}$ enhancement. Particularly high Aitken particle mode concentrations compared to the accumulation mode concentrations were found. The accumulation mode of aerosol particles in North American boreal fire pollution plumes detected in this POLARCAT study is less pronounced as compared to Fiebig et al. (2003) and Petzold 
et al. (2007), which may be explained by the different measurement locations and most likely aerosol scavenging via clouds. Analysis from thermodenuder measurements illustrate that the external mixture of North American BF accumulation mode particles contain a volume fraction of up to $25-30 \%$ of refractory material at the applied temperature of $280^{\circ} \mathrm{C}$. North American anthropogenic air masses can be clearly distinguished from BF air masses, containing only $5 \%$ of refractory material in the accumulation mode. In contrast to BF air masses, the anthropogenic (AN) air mass seems to be internally mixed. In addition, most particles are somewhat composed of a non volatile fraction which can be $\mathrm{BC}$, but also less volatile organic material $\left(\right.$ at $280^{\circ} \mathrm{C}$ ). This finding is true for both categories, namely $\mathrm{AN}$ as well as BF air mass particles.

We finally state that pollution from North America contained only small amounts of BC mass concentrations and was mainly composed of sulphate (particularly dominating anthropogenic air mass) and organics during the summer measurement period within POLARCAT. No significant amounts of $\mathrm{BC}$ mass were transported to Greenland from the North American continent, at least not during the summer observation period. Hence, there was a low potential of $\mathrm{BC}$ deposition (dry and wet) from North American pollution plumes on the Greenland surface ice/snow and therefore, limited impact on the surface albedo during POLARCAT Arctic summer observational period. To answer the question if the above findings for North American pollution plume can be generalised, more measurements and modeling studies are needed in the future.

Acknowledgements. The authors would like to thank the French research agencies ANR, CNES, CNRS-INSU, and IPEV as well as EUFAR. We acknowledge funding by the German Research Foundation (DFG) through the SPP 1294, by the state-"Exzellenzcluster Geocycles" of Rheinland-Pfalz, and by the Max Planck Society. NILU researchers were supported by the Norwegian Research Council in the framework of POLARCAT-Norway and CLIMSLIPLEFE. We also would like to thank SAFIRE and Christophe Gourbeyre for their support during the planning and execution of the French ATR-42 campaigns and, together with DT-INSU, for help with instrument integration. Finally, we gratefully acknowledge the NOAA Air Resources Laboratory (ARL) providing the HYSPLIT transport and dispersion model and/or the READY website (http://www.arl.noaa.gov/ready.php) used in this publication.

Edited by: P. Quinn

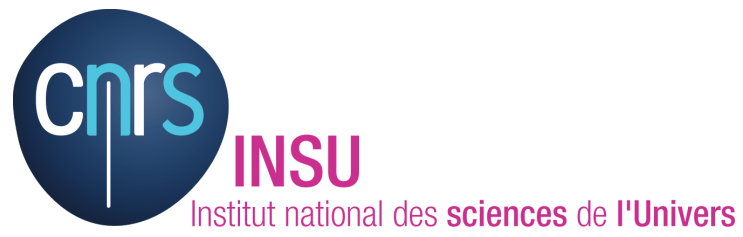

The publication of this article is financed by CNRS-INSU.

\section{References}

Anderson, T. L., Covert, D., Wheeler, J., Harris, J., Perry, K., Trost, B., Jaffe, D., and Ogren, J.: Aerosol backscatter fraction and single scattering albedo: Measured values and uncertainties at a coastal station in Pacific Northwest, J. Geophys. Res., 104, 26793-26807, 1999.

Andreae, M. O. and Merlet, P.: Emission of trace gases and aerosols from biomass burning, Global Biogeochem. Cy., 15, 955-966, doi:10.1029/2000GB001382, 2001.

Barnard, J. C., Kassianov, E. I., Ackerman, T. P., Johnson, K., Zuberi, B., Molina, L. T., and Molina, M. J.: Estimation of a "radiatively correct" black carbon specific absorption during the Mexico City Metropolitan Area (MCMA) 2003 field campaign, Atmos. Chem. Phys., 7, 1645-1655, doi:10.5194/acp-7-1645-2007, 2007.

Bohren, C. and Huffman, D.: Absorption and scattering of light by small particles, John Wiley, New York, 1983.

Bond, T. C. and Bergstrom, R. W.: Light Absorption by Carbonaceous Particles: An Investigative Review, Aerosol Sci. Technol., 40, 27-67, doi:10.1080/02786820500421521, 2006.

Bond, T. C., Anderson, T. L., and Campbell, D.: Calibration and intercomparison of filter-based measurements of visible light absorption by aerosols, Aerosol Sci. Technol., 30, 582-600, 1999.

Bond, T. C., Habib, G., and Bergstrom, R. W.: Limitations in the enhancement of visible light absorption due to mixing state, J. Geophys. Res., 111, D20211, doi:10.1029/2006JD007315, 2006.

Brock, C., Radke, L., and Hobbs, P.: Sulfur in particles in Arctic hazes derived from airborne in situ and lidar measurements, J. Geophys. Res., 95, 22369-22387, 1990.

Brock, C. A., Cozic, J., Bahreini, R., Froyd, K. D., Middlebrook, A. M., McComiskey, A., Brioude, J., Cooper, O. R., Stohl, A., Aikin, K. C., de Gouw, J. A., Fahey, D. W., Ferrare, R. A., Gao, R.-S., Gore, W., Holloway, J. S., Hbler, G., Jefferson, A., Lack, D. A., Lance, S., Moore, R. H., Murphy, D. M., Nenes, A., Novelli, P. C., Nowak, J. B., Ogren, J. A., Peischl, J., Pierce, R. B., Pilewskie, P., Quinn, P. K., Ryerson, T. B., Schmidt, K. S., Schwarz, J. P., Sodemann, H., Spackman, J. R., Stark, H., Thomson, D. S., Thornberry, T., Veres, P., Watts, L. A., Warneke, C., and Wollny, A. G.: Characteristics, sources, and transport of aerosols measured in spring 2008 during the aerosol, radiation, and cloud processes affecting Arctic Climate (ARCPAC) Project, Atmos. Chem. Phys., 11, 2423-2453, doi:10.5194/acp-11-24232011, 2011.

Browell, E., Butler, C., Kooi, S., Fenn, M., Harriss, R., and Gregory, G.: Large scale variability of ozone and aerosols in the summertime Arctic and sub-Arctic troposphere, J. Geophys. Res., 97, 16433-16450, 1992.

Canagaratna, M., Jayne, J., Jimenez, J., Allan, J., Alfarra, M., Zhang, Q., Onasch, T., Drewnick, F., Coe, H., Middlebrook, A., Delia, A., Williams, L., Trimborn, A., Northway, M., DeCarlo, P., Kolb, C., Davidovits, P., and Worsnop, D.: Chemical and microphysical characterization of ambient aerosols with the aerodyne aerosol mass spectrometer, Mass Spectrom. Rev., 26, 185-222, doi:10.1002/mas.20115, 2007.

Doherty, S. J., Quinn, P. K., Jefferson, A., Carrico, C. M., Anderson, T. L., and Hegg, D.: A comparison and summary of aerosol optical properties as observed in situ from aircraft, ship and land during ACE-Asia, J. Geophys. Res., 110, D04201, doi:10.1029/2004JD004964, 2005. 
Draxler, R. R. and Rolph, G. D.: HYSPLIT (HYbrid Single-Particle Lagrangian Integrated Trajectory) Model access via NOAA ARL READY Website (http://ready.arl.noaa.gov/HYSPLIT. php), NOAA Air Resources Laboratory, Silver Spring, MD, 2010.

Dreiling, V. and Friederich, B.: Spatial distribution of the arctic haze aerosol size distribution in western and eastern Arctic, Atmospheric research, 44, 133-152, doi:10.1016/S01698095(96)00035-X, 1997.

Drewnick, F., Hings, S. S., DeCarlo, P., Jayne, J. T., Gonin, M., Fuhrer, K., Weimer, S., Jimenez, J. L., Demerjian, K. L., Borrmann, S., and Worsnop, D. R.: A New Time-of-Flight Aerosol Mass Spectrometer (TOF-AMS)-Instrument Description and First Field Deployment, Aerosol Sci. Technol., 39, 637-658, doi:10.1080/02786820500182040, 2005.

Eckhardt, S., Stohl, A., Beirle, S., Spichtinger, N., James, P., Forster, C., Junker, C., Wagner, T., Platt, U., and Jennings, S. G.: The North Atlantic Oscillation controls air pollution transport to the Arctic, Atmos. Chem. Phys., 3, 1769-1778, doi:10.5194/acp3-1769-2003, 2003.

Fiebig, M., Stohl, A., Wendisch, M., Eckhardt, S., and Petzold, A.: Dependence of solar radiative forcing of forest fire aerosol on ageing and state of mixture, Atmos. Chem. Phys., 3, 881-891, doi:10.5194/acp-3-881-2003, 2003.

Forster, C., Wandinger, U., Wotawa, G., James, P., Mattis, I., Althausen, D., Simmonds, P., O'Doherty, S., Jennings, S. G., Kleefeld, C., Schneider, J., Trickl, T., Kreipl, S., Jäger, H., and Stohl, A.: Transport of boreal forest fire emissions from Canada to Europe, J. Geophys. Res., 106, 22887-22906, doi:10.1029/2001JD900115, 2001.

Garrett, T. J. and Zhao, C.: Increased Arctic cloud longwave emissivity associated with pollution from mid-latitudes, Nature, 787789, 2006

Giglio, L., Descloitres, J., Justice, C. O., and Kaufman, Y.: An enhanced contextual fire detection algorithm for MODIS, Remote Sens. Environ., 87, 273-282, doi:10.1016/S00344257(03)00184-6, 2003

Greenaway, K. R.: Experiences with Arctic flying weather, Royal Meteorol. Soc. Can. Branch, Toronto, Ont., Canada, 1950.

Heald, C. L., Jacob, D. J., Alexander, B., Fairlie, T. D., Yantosca, R. M., and Chu, D. A.: Transpacific transport of Asian anthropogenic aerosols and its impact on surface air quality in the United States, J. Geophys. Res., 111, D14310, doi:10.1029/2005JD006847, 2006.

Hinds, W. C.: Aerosol technology: properties, behaviour and measurement of airborne particles, Wiley-Interscience, 1999.

Hirdman, D., Sodemann, H., Eckhardt, S., Burkhart, J. F., Jefferson, A., Mefford, T., Quinn, P. K., Sharma, S., Ström, J., and Stohl, A.: Source identification of short-lived air pollutants in the Arctic using statistical analysis of measurement data and particle dispersion model output, Atmos. Chem. Phys., 10, 669-693, doi:10.5194/acp-10-669-2010, 2010.

Honrath, R. E., Owen, R. C., Val Martin, M., Reid, J. S., Lapina, K., Fialho, P., Dziobak, M. P., Kleissl, J., and Westphal, D. L.: Regional and hemispheric impacts of anthropogenic and biomass burning emissions on summertime $\mathrm{CO}$ and $\mathrm{O}_{3}$ in the North Atlantic lower free troposphere, J. Geophys. Res., 109, D24310, doi:10.1029/2004JD005147, 2004.

Hosseini, S., Li, Q., Cocker, D., Weise, D., Miller, A., Shrivas- tava, M., Miller, J. W., Mahalingam, S., Princevac, M., and Jung, H.: Particle size distributions from laboratory-scale biomass fires using fast response instruments, Atmos. Chem. Phys., 10, 80658076, doi:10.5194/acp-10-8065-2010, 2010.

Huang, L., Gong, S. L., Sharma, S., Lavoué, D., and Jia, C. Q.: A trajectory analysis of atmospheric transport of black carbon aerosols to Canadian high Arctic in winter and spring (1990 2005), Atmos. Chem. Phys., 10, 5065-5073, doi:10.5194/acp10-5065-2010, 2010.

IPCC: Climate Change 2007: Synthesis Report. Contribution of Working groups I, II and III to the fourth Assessement Report of the Intergouvernemental Panel on Climate Change, edited by: Core Writing Team, Pachauri, R. K., and Reisinger, A., IPCC, Geneva, Switzerland, 2007.

Iziomon, M. G., Lohmann, U., and Quinn, P. K.: Summertime pollution event int the Arctic and potential implications, J. Geophys. Res., 111, D12206, doi:10.1029/2005JD006223, 2006.

Law, K. S. and Stohl, A.: Arctic Air Pollution: Origins and Impacts, Science, 315, 1537-1540, doi:10.1126/science.1137695, 2007.

Lubin, D. and Vogelmann, A. M.: A climatologically significant aerosol longwave indirect effect in the Arctic, Nature, 439, 453456, 2006.

Masonis, S. J., Franke, K., Ansmann, A., Müller, D., Althausen, D., Ogren, J. A., Jefferson, A., and Sheridan, P. J.: An intercomparison of aerosol light extinction and $180^{\circ}$ backscatter as derived using in-situ instruments and Raman lidar during INDOEX field campaign, J. Geophys. Res., 107, 8014, doi:10.1029/2000JD000035, 2002.

Mätzler, C.: MATLAB Functions for Mie scattering and absorption, Institut für Angewandte Physik, Research report No. 2002-08, Bern, Switzerland, 2002.

McConnell, J. R., Edwards, R., Kok, G. L., Flanner, M. G., Zender, C. S., Saltzman, E. S., Banta, J. R., Pasteris, D. R., Carter, M. M., and Kahl, J. D. W.: 20th-century industrial black carbon emissions altered Arctic climate forcing, Science, 317, 1381-1384, doi:10.1126/science.1144856, 2007.

McNaughton, C. S., Clarke, A. D., Howell, S. G., Pinkerton, M., Anderson, B., Thornhill, L., Hudgins, C., Winstead, E., Dibb, J. E., Scheuer, E., and Maring, H.: Results from the DC-8 inlet characterization experiment (DICE): Airborne versus surface sampling of mineral dust and sea salt aerosols, Aerosol Sci. Technol., 41, 136-159, doi:10.1080/02786820601118406, 2007.

Mitchell, J. M.: Visual range in the polar regions with particular reference to the Alaskan Arctic, J. Atmos. Terr. Phys. Spec., Suppl., 195-211, 1957.

Neédélec, P., Cammas, J.-P., Thouret, V., Athier, G., Cousin, J.-M., Legrand, C., Abonnel, C., Lecoeur, F., Cayez, G., and Marizy, C.: An improved infrared carbon monoxide analyser for routine measurements aboard commercial Airbus aircraft: technical validation and first scientific results of the MOZAIC III programme, Atmos. Chem. Phys., 3, 1551-1564, doi:10.5194/acp-3-15512003, 2003.

Paris, J.-D., Stohl, A., Nédélec, P., Arshinov, M. Yu., Panchenko, M. V., Shmargunov, V. P., Law, K. S., Belan, B. D., and Ciais, P.: Wildfire smoke in the Siberian Arctic in summer: source characterization and plume evolution from airborne measurements, Atmos. Chem. Phys., 9, 9315-9327, doi:10.5194/acp-9-9315-2009, 2009.

Paris, J.-D., Stohl, A., Ciais, P., Nédélec, P., Belan, B. D., Arshi- 
nov, M. Yu., and Ramonet, M.: Source-receptor relationships for airborne measurements of $\mathrm{CO}_{2}, \mathrm{CO}$ and $\mathrm{O}_{3}$ above Siberia: a cluster-based approach, Atmos. Chem. Phys., 10, 1671-1687, doi:10.5194/acp-10-1671-2010, 2010.

Petzold, A., Weinzierl, B., Huntrieser, H., Stohl, A., Real, E., Cozic, J., Fiebig, M., Hendricks, J., Lauer, A., Law, K., Roiger, A., Schlager, H., and Weingartner, E.: Perturbation of the European free troposphere aerosol by North American forest fire plumes during the ICARTT-ITOP experiment in summer 2004, Atmos. Chem. Phys., 7, 5105-5127, doi:10.5194/acp-7-51052007, 2007.

Quinn, P. K., Miller, T. L., Bates, T. S., Ogren, J. A., Andrews, E., and Shaw, G. E.: A three-year record of simultaneously measured aerosol chemical and optical properties at Barrow, Alaska, J. Geophys. Res., 107, 4130, doi:10.1029/2001JD001248, 2002.

Quinn, P. K., Andrews, B., Christensen, J., Dutton, E., and Shaw, G.: Acifdifying pollutants, Arctic haze, and acification in the Arctic, Arctic Research of the United States, 19, 2005.

Quinn, P. K., Shaw, G., Andrews, E., Dutton, E. G., RuohoAirola, T., and Gong, S. L.: Arctic Haze: Current trend and knowledge gaps, Tellus B, 59, 99-114, doi:10.1111/j.16000889.2006.00238.x, 2007.

Quinn, P. K., Bates, T. S., Baum, E., Doubleday, N., Fiore, A. M., Flanner, M., Fridlind, A., Garrett, T. J., Koch, D., Menon, S., Shindell, D., Stohl, A., and Warren, S. G.: Short-lived pollutants in the Arctic: their climate impact and possible mitigation strategies, Atmos. Chem. Phys., 8, 1723-1735, doi:10.5194/acp8-1723-2008, 2008.

Real, E., Law, K. S., Weinzierl, B., Fiebig, M., Petzold, A., Wild, O., Methven, J., Arnold, S., Stohl, A., Huntrieser, H., Roiger, A., Schlager, H., Stewart, D., Avery, M., Sachse, G., Browell, E., Ferrare, R., and BLake, D.: Processes influencing ozone levels in Alaskan forest fire plumes during long-range transport over the North Atlantic, J. Geophys. Res., 112, D10S41, doi:10.1029/2006JD007576, 2007.

Reid, J. S., Hobbs, P. V., Ferek, R. J., Blake, D. R., Martins, J. V., Dunlap, M. R., and Liousse, C.: Physical, chemical, and optical properties of regional hazes dominated by smoke in Brazil, J. Geophys. Res., 103, 32059-32080, doi:10.1029/98JD00458, 1998.

Reid, J. S., Koppmann, R., Eck, T. F., and Eleuterio, D. P.: A review of biomass burning emissions part II: intensive physical properties of biomass burning particles, Atmos. Chem. Phys., 5, 799825, doi:10.5194/acp-5-799-2005, 2005.

Ricard, V., Jaffrezo, J., Kerminen, V., Hillamo, R. E., Sillanpaa, M., Ruellan, S., Liousse, C., and Cachier, H.: Two years of continuous aerosol measurements in northern Finland, J. Geophys. Res., 107, 4129, doi:10.1029/2001JD000952, 2002.

Rolph, G. D.: Real-time Environmental Applications and Display sYstem (READY) Website (http://ready.arl.noaa.gov), NOAA Air Resources Laboratory, Silver Spring, MD, 2010.

Schmale, J., Schneider, J., Jurkat, T., Voigt, C., Kalesse, H., Rautenhaus, M., Lichtenstern, M., Schlager, H., Ancellet, G., Arnold, F., Gerding, M., Mattis, I., Wendisch, M., and Borrmann, S.: Aerosol layers from the 2008 eruptions of Mount Okmok and Mount Kasatochi: In situ upper troposphere and lower stratosphere measurements of sulfate and organics over Europe, J. Geophys. Res., 115, D00L07, doi:10.1029/2009JD013628, 2010 .
Schmale, J., Schneider, J., Ancellet, G., Quennehen, B., Stohl, A., Sodemann, H., Burkhart, J. F., Hamburger, T., Arnold, S. R., Schwarzenboeck, A., Borrmann, S., and Law, K. S.: Source identification and airborne chemical characterisation of aerosol pollution from long-range transport over Greenland during POLARCAT summer campaign 2008, Atmos. Chem. Phys., 11, 1009710123, doi:10.5194/acp-11-10097-2011, 2011.

Schnell, R. C.: Arctic haze and the Arctic Gas and Aerosol Sampling Program (AGASP), Geophys. Res. Letters, 11, 361-364, doi:10.1029/GL011i005p00361, 1984.

Schwarz, J. P., Gao, R. S., R., S. J., Watts, L. A., Thomson, D. S., Fahey, D., Ryerson, T. B., Peischl, J., Holloway, J. S., Trainer, M., Baynard, T., Lack, D. A., De Gouw, J. A., Warneke, C., and Del Negro, L. A.: Measurement of the mixing state, mass, and optical size of individual black carbon particles in urban and biomass burning emissions, J. Geophys. Res., 35, L13810, doi:10.1029/2008GL033968, 2008.

Sharma, S., Brook, J. R., Cachier, H., Chow, J., Gaudenzi, A., and Lu, G.: Light absorption and thermal measurements of black carbon in different regions of Canada, J. Geophys. Res., 107, 4771, doi:10.1029/2002JD002496, 2002.

Sharma, S., Lavoué, D., Cachier, H., Barrie, L. A., and Gong, S. L.: Long-term trends of black carbon concentrations in the Canadian Arctic, J. Geophys. Res., 109, D15203, doi:10.1029/2003JD004331, 2004.

Sharma, S., Andrews, E., Barrie, L. A., Ogren, J. A., and Lavoué, D.: Variations and sources of the equivalent black carbon in the high Arctic revealed bu long-term observations at Alert and Barrow 1989-2003, J. Geophys. Res., 111, D14208, doi:10.1029/2005JD006581, 2006.

Shaw, G. E.: The vertical distribution of atmospheric aerosols at Barrow, Alaska, Tellus, 27, 39-50, 1975.

Sheridan, P. J., Jefferson, A., and Ogren, J.: Spatial variability of submicrometer aerosol radiative properties over the Indian Ocean during INDOEX, J. Geophys. Res., 107(D19), 8011, doi:10.1029/2000JD000166, 2002.

Singh, H. B., Anderson, B. E., Brune, W. H., Cai, C., Cohen, R. C., Crawford, J. H., Cubison, M. J., Czech, E. P., Emmons, L., Fuelberg, H. E., Huey, G., Jacob, D. J., Jimenez, J. L., Kaduwela, A., Kondo, Y., Mao, J., Olson, J. R., Sachse, G. W., Vay, S. A., Weinheimer, A., Wennberg, P. O., and Wisthaler, A.: Pollution influence on atmospheric composition and chemistry at high northern latitudes: Boreal and California forest fire emissions, Atmos. Environ., 44, 4553-4564, doi:10.1016/j.atmosenv.2010.08.026, 2010.

Sirois, A. and Barrie, L.: Arctic lower troposheric aerosol trends and composition at Alert, Canada: 1980-1995, J. Geophys. Res., 104, 11599-11618, doi:10.1029/1999JD900077, 1999.

Springston, S. R. and Sedlacek, A. J. I.: Noise characteristics of an instrumental particle absorbance technique, Aerosol Sci. Technol., 41, 1110-1116, doi:10.1080/02786820701777457, 2007.

Stohl, A.: Characteristics of atmospheric transport into the Arctic troposphere, J. Geophys. Res., 111, 148-227, doi:10.1029/2005JD006888, 2006.

Stohl, A., Hittenberger, M., and Wotawa, G.: Validation of the lagrangian particle dispersion model FLEXPART against largescale tracer experiment data, Atmos. Environ., 32, 4245-4264, doi:10.1016/S1352-2310(98)00184-8, 1998.

Stohl, A., Forster, C., Eckhardt, S., Spichtinger, N., Huntrieser, H., 
Heland, J., Schlager, H., Wilhelm, F., Arnold, F., and Cooper, O.: backward modeling study of intercontinental pollution transport using aircraft measurements, J. Geophys. Res., 108, 4370, doi:10.1029/2002JD002862, 2003.

Stohl, A., Forster, C., Frank, A., Seibert, P., and Wotawa, G.: Technical note: The Lagrangian particle dispersion model FLEXPART version 6.2, Atmos. Chem. Phys., 5, 2461-2474, doi:10.5194/acp-5-2461-2005, 2005.

Stohl, A., Andrews, E., Burkhart, J. F., Forster, C., Herber, A., Hoch, S. W., Kowal, D., Lunder, C., Mefford, T., Ogren, J. A., Sharma, S., Spichtinger, N., Stebel, K., Stone, R., Strm, J., Trseth, K., Wehrli, C., and Yttri, K. E.: Pan-Arctic enhancements of light absorbing aerosol concentrations due to North American boreal forest fires during summer 2004, J. Geophys. Res., 111, 148-227, doi:10.1029/2006JD007216, 2006.

Stohl, A., Berg, T., Burkhart, J. F., Fjæraa, A. M., Forster, C., Herber, A., Hov, Ø., Lunder, C., McMillan, W. W., Oltmans, S., Shiobara, M., Simpson, D., Solberg, S., Stebel, K., Ström, J., Tørseth, K., Treffeisen, R., Virkkunen, K., and Yttri, K. E.: Arctic smoke - record high air pollution levels in the European Arctic due to agricultural fires in Eastern Europe in spring 2006, Atmos. Chem. Phys., 7, 511-534, doi:10.5194/acp-7-511-2007, 2007.
Twomey, S.: The Influence of Pollution on the Shortwave Albedo of Clouds, J. Atmos. Sci., 34, 1149-1152, doi:10.1175/15200469(1977)034;1149:TIOPOT i2.0.CO;2, 1977.

Villani, P., Picard, D., Michaud, V., Laj, P., and Wiedensohler, A.: Design and Validation of a Volatility Hygroscopic Tandem Differential Mobility Analyzer (VH-TDMA) to Characterize the Relationships Between the Thermal and Hygroscopic Properties of Atmospheric Aerosol Particles, Aerosol Sci. Technol., 42, 729_ 741, 2008.

Wiedensohler, A., Birmili, W., Nowak, A., Sonntag, A., Weinhold, K., Merkel, M., Wehner, B., Tuch, T., Pfeifer, S., Fiebig, M., Fjäraa, A. M., Asmi, E., Sellegri, K., Depuy, R., Venzac, H., Villani, P., Laj, P., Aalto, P., Ogren, J. A., Swietlicki, E., Roldin, P., Williams, P., Quincey, P., Hüglin, C., Fierz-Schmidhauser, R., Gysel, M., Weingartner, E., Riccobono, F., Santos, S., Grüning, C., Faloon, K., Beddows, D., Harrison, R. M., Monahan, C., Jennings, S. G., O’Dowd, C. D., Marinoni, A., Horn, H.-G., Keck, L., Jiang, J., Scheckman, J., McMurry, P. H., Deng, Z., Zhao, C. S., Moerman, M., Henzing, B., and de Leeuw, G.: Particle mobility size spectrometers: harmonization of technical standards and data structure to facilitate high quality long-term observations of atmospheric particle number size distributions, Atmos. Meas. Tech. Discuss., 3, 5521-5587, doi:10.5194/amtd-3-55212010, 2010. 